\title{
Ancestral Dravidian languages in Indus Civilization: ultraconserved Dravidian tooth-word reveals deep linguistic ancestry and supports genetics
}

Bahata Ansumali Mukhopadhyay (D) ${ }^{1 凶}$

Ever since the discovery of Indus valley civilization, scholars have debated the linguistic identities of its people. This study analyzes numerous archaeological, linguistic, archaeogenetic and historical evidences to claim that the words used for elephant (like, 'pīri', 'pīru') in Bronze Age Mesopotamia, the elephant-word used in the Hurrian part of an Amarna letter of ca. 1400 BC, and the ivory-word ('pîruš') recorded in certain sixth century BC Old Persian documents, were all originally borrowed from 'pillu', a Proto-Dravidian elephant-word, which was prevalent in the Indus valley civilization, and was etymologically related to the ProtoDravidian tooth-word '*pal' and its alternate forms ('* pil'/"*pil'/“*pel'). This paper argues that there is sufficient morphophonemic evidence of an ancient Dravidian '*pil'/"*pil'-based root, which meant 'splitting/crushing', and was semantically related to the meanings 'tooth/tusk'. This paper further observes that 'pillu' is among the most ancient and common phytonyms of the toothbrush tree Salvadora persica, which is a characteristic flora of Indus valley, and whose roots and twigs have been widely used as toothbrush in IVC regions since antiquity. This study claims that this phytonym 'pillu' had also originated from the same Proto-Dravidian tooth-word, and argues that since IVC people had named their toothbrush trees and tuskers (elephants) using a Proto-Dravidian tooth-word, and since these names were widely used across IVC regions, a significant population of Indus valley civilization must have used that Proto-Dravidian tooth-word in their daily communication. Since 'tooth' belongs to the core non-borrowable ultraconserved vocabulary of a speech community, its corollary is that a significant population of IVC spoke certain ancestral Dravidian languages. Important insights from recent archaeogenetic studies regarding possible migration of Proto-Dravidian speakers from Indus valley to South India also corroborate the findings of this paper.

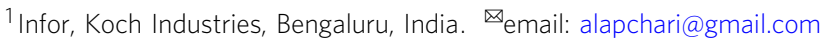




\section{Introduction}

Indus valley civilization (IVC) and its linguistic diversity. IVC, stretching across almost one million square kilometres of Pakistan, Afghanistan, and the North-Western part of India (Kenoyer, 2010), was the most expansive of chalcolithic civilizations. Right from the discovery of IVC and its enigmatic script, several scholars have tried to trace the types of languages spoken in IVC. Types of languages presently spoken in the IVC regions are: IndoAryan (e.g., Punjabi in Punjab with dialects Siraiki and Lahnda, Sindhi in Sindh, Hindi, Marwari, Gujarati in eastern parts of Greater Indus Valley); Dardic (e.g., Shina, Khowar, Kohistani); Iranian (e.g., Baluchi, Dari, Pashto, and Wakhi in western parts of Greater Indus Valley); Nuristani in northeastern Afghanistan; Dravidian; Brahui (spoken in Baluchistan and Sindh); and Burushaski (a language isolate) spoken in northernmost Pakistan close to the Chinese border (Parpola, 2015, pp. 163-164).

Since the ancient world was generally more multilinguistic (12,000-20,000 languages existed before spread of agriculture, compared to some 7000 human languages of present times) (Pagel, 2009), ancient IVC too arguably hosted more languages than today. This makes it unlikely that all the languages spoken in its $1,00,0000$ square-kilometre expanse belonged to only one linguistic group, whether Proto-Indo-Aryan, Proto-Dravidian or Proto-Austroasiatic. Languages of various groups, including some presently extinct languages (Masica, 1979), might have coexisted in IVC for ages, influencing and shaping one another.

\section{The perennial puzzle regarding IVC languages: how archae- ologists, linguists, historians and genetic anthropologists approach the problem}

Arguments from archaeology and linguistics. Incommoded by the absence of any deciphered written record composed in IVC (Indus script is still undeciphered), scholars hold vastly different opinions regarding types of languages spoken in IVC. Once an advocate of the idea of a 'Para-Munda' (not 'Proto-Munda') speaking IVC (Witzel, 1999, 2000, 2009), Witzel, presently prefers keeping the question of 'original' Indian language(s) 'open', till better reconstructions of Dravidian and Munda languages, and investigation of substrate words of ancient indigenous languages present in North-Indian Indo-Aryan languages are done (Witzel, 2019). While many linguists (Parpola, 2015; Driem, 1999; Osada, 2006) have opposed the Austroasiatic-related hypotheses regarding IVC's languages, Southworth (2004, pp. 325-328) shares Witzel's 'Para-Munda' theory, despite vigorously advancing the idea of prehistoric Dravidian influence on various languages presently spoken in IVC regions (e.g., Sindh, Gujarat, Maharashtra). Although some scholars claim that IVC language (s) belonged to some Proto-Indo-Aryan/Early-Indo-European language group (Renfrew, 1987, pp. 185-208; Rao, 1982), many others (e.g., Krishnamurti, 2003, p. 501; Parpola, 1994) defend a Proto-Dravidian speaking IVC. Parpola $(1988,1994,2015)$ proposes Proto-Dravidian etymologies of suspect substrate words (e.g., kiyāmbu, śakațam, om, kinnara) present in Vedic texts, and certain suspect Indic words found in Mesopotamian texts (the 'magilum' boats of Meluhha); suggests that some of the fish-like signs of Indus script represented the Dravidian fish-word 'mina', to spell out certain Dravidian theophoric astral names prevalent in IVC; and adduces additional anthropological and ethnographic proofs of Dravidian influence, including Dravidian kinship and cross-cousin marriage rules practiced in the presently Indo-Aryan speaking societies of IVC regions (e.g. Gujarat). Though the prehistoric existence of 'Language $\mathrm{X}$ ', an unknown primordial language not of proto-Indo-Aryan, Proto-Dravidian, or ProtoMunda type, was suggested by Masica's (1979) analysis of various agricultural terms prevalent in some North-Indian languages,
Masica (1991, p. 40) has later commented that the Dravidian stock is "a strong but as yet unproven contender for the languages of the Harappans".

Despite many such scholarly works, very few linguistic evidences, enjoying enough archaeological support to irrefutably identify the language(s) of IVC, have been offered so far. The situation is even more complicated due to several unresolved questions around the prehistoric spatio-temporal expanse of some major linguistic groups of present India (Indo-Aryan, Dravidian, and Austroasiatic), and their influences over one another. Dravidian-group languages, despite being spoken mostly in southern India (e.g., Tamil, Telugu, Kannada, Malayalam), also have scattered representations in India's North-Western (Brahui), North-Eastern (Kurux, Malto), and Central (e.g., Kolami, Naiki, Parji, Ollari, Gadaba) parts, indicating that Dravidian speakers possibly had much greater pre-historic presence in Northern India, including IVC regions (Southworth, 2004). Moreover, Mathematical linguistic studies confirm that Proto-Dravidian existed in the time of IVC (Pagel et al., 2013; Kolipakam et al., 2018). Similarly, though Austroasiatic languages (e.g., Mundari, Santali, Khasi) are currently spoken mostly in North-Eastern India, presence of the isolated Austroasiatic language Korku amidst Dravidian-speaking Gondis and other Indo-Aryan speakers in Madhya Pradesh and Maharashtra, indicates the possibility of a wider Austroasiatic presence in pre-historic India (Southworth, 2004). Such uncertainties about spatio-temporal expanse assail even Indo-Aryan languages, the most dominant language-group of present North India, which has provided us with Rgveda and Atharvaveda, the oldest Indian texts composed in Sanskrit. Whether Indo-Aryan languages entered India from outside after IVC's decline, or were present in India since or from before the IVC era and were spoken in IVC, are questions that have enjoyed almost 200 years of scholarly attention (Bryant and Patton, 2005), along with innumerable amateurish attempts, often motivated by identity-politics.

Arguments from archaeogenetics. Parallel to archaeology and linguistics, archaeogenetics can immensely help us reconstruct the linguistic pre-history of a region. For example, a recent crossdisciplinary archaeogenetic study (Narasimhan et al., 2019), not only infers "a likely genetic signature for people of the IVC" (p. 2), but also suggests interesting theories regarding ProtoDravidian's spread. This study postulates that having different proportions of Iranian-farmer-related ancestry and AncientAncestral-South-Indian-related ancestry "was a characteristic feature of many IVC people" (p. 12). It states that after "IVC's decline, this population mixed with northwestern groups with Steppe ancestry, to form 'Ancestral North Indians' (ANI), and also mixed with southeastern groups to form 'Ancestral South Indians' (ASI), whose direct descendants today live in tribal groups in southern India" (p. 1). It argues that "[m]ixtures of these two post-IVC groups-the ANI and ASI-drive the main gradient of genetic variation in South Asia today" (p. 1).

Most relevantly, this archaeogenetic study states that quite possibly "Proto-Dravidian was spread by peoples of IVC along with the Indus Periphery Cline ancestry component of the ASI [Ancestral-South-Indian]" (p. 13). [Here Indus Periphery Cline refers to the ethnicity of 11 IVC-era individuals whose remains were recovered from burials of two sites in cultural contact with IVC. These individuals are conjectured to be migrants from IVC, as their genomes do not fit the genomes of the core population found in their burial-sites, but fit well with genomes of 86 PostIVC (1200-800 BC) people living near the headwaters of river Indus, and also genomes of diverse present-day South-Asians]. However, Narasimhan et al. do not deny the alternative 
possibility that "Proto-Dravidian was spread by the half of the ASI's ancestry that was not from the Indus Periphery Cline and instead derived from the south and the east (peninsular South Asia)" (p. 13).

Another related genomic study (Shinde et al., 2019) analyzes the genome of one IVC-era individual from Rakhigarhi, a longstanding Indus settlement, and discusses how that individual shared the same Iranian-farmer-related ancestry as of Indus Periphery Cline individuals, but little if any Steppe pastoralist-derived ancestry, and how this Iranian-farmer-related ancestry had diverged from the western Iranian people since at least $8000 \mathrm{BC}$.

Genetic ancestries and languages not being always linearly correlated, these studies, although quite helpful, do not suffice for a sure call regarding the dominant linguistic group(s) extant in IVC. For, they do not tell us which language(s) were spoken by the IVC's ancestors, after their ancestors, and predecessors of western Iranian people had split around $8000 \mathrm{BC}$. Nor can the genetic data surely say if Dravidian languages originated in IVC or in the southern Indian peninsula.

How the present paper solves a part of the puzzle. This study seeks to resolve a crucial part of this perennial puzzle of South Asian prehistory, through establishing the certain existence of ancestral Dravidian language(s) in IVC. In the absence of any deciphered written documents of IVC, we have no direct way of identifying Harappan languages. So, the only feasible starting point is finding some proto-words which meet most of the following criteria:

i. Historical and linguistic evidence indicates that IVC was the most likely origin of those proto-words.

ii. Archaeological evidence indicates that the objects signified by those proto-words were prevalently produced and used in IVC.

iii. Those proto-words' etymologies can be traced back to one of the language groups present in the Indian sub-continent using the most stringent criteria prescribed in historical linguistics.

iv. Historical and linguistic evidence should prove that the identified language group was present in the Indian subcontinent in the IVC era.

v. Archaeogenetic data should prove that present speakers of this language group are significantly genetically related to the IVC population.

vi. The proto-words should be etymologically related to the stable non-borrowable basic vocabulary of a language, which can trace out a language's ancestry.

Fortunately, we do have such proto-words. Since IVC had a thriving trading relationship with Persian Gulf and Mesopotamia, this study has searched through ancient Near-Eastern texts, hoping to find certain fossilized foreign words which had their origin in IVC. The logic is that when we import a foreign commodity not locally produced, we usually call it by its foreign name. This intuitive approach has been duly rewarded, as it is found that the words 'pirru'/'pīri' and their various dialectal variations, which signified elephant in Akkadian and ivory ('pirus') in Old-Persian, are perfect tools for the present endeavour. My study argues that since archaeological data strongly associates Near Eastern ivory-objects of middle-third to early-second millennium BC with Asian elephants and IVC traders (Frenez, 2018a; Olijdam and David-Cuny, 2018), and since the ivory-words (e.g., 'ab', 'abu', 'ảb', 'behu', 'netcheh-t') used in ancient Egypt (the only other major source of prehistoric ivory), (Budge, 1920), has no phonetic connection to 'piru', these 'pirru'-based words could likely have originated in IVC.
Strong linguistic evidence corroborating the above hypothesis comes from ancient Indic languages. In several Dravidian languages, 'pīlu', 'pella', 'palla', 'pallava', 'pilluvam', 'pīluru', etc., signify elephant (Narain, 1991 p. 25; Kittel, 1894; Brown, 1903; Madras Tamil lexicon, 1924-36). Moreover, in present Dravidian languages, the most popular word for female elephant is 'pidii' (Burrow and Emeneau, 1984), which is also reconstructed as a Proto-Dravidian word '*pide-i' (Starostin, 2006-2013). Now, cerebral ' 1 ', ' $\mathbf{d}$ ', are ' $r$ ' are intimately allied and highly interchangeable in Dravidian languages (Caldwell, 1875, p. 33, 59). For example, the word for fowl is pronounced as 'kōiri', 'kọ̣̄i', and 'kolili' in Tamil, Telugu, and Kannada, respectively. Even for the very term 'dravidua' (from which 'Dravidian' is derived), that meant southern Indian people and their country in ancient Sanskrit, Buddhist, and Jain texts, there were other forms such as 'dramila', 'dramila', and 'damila', among which the '!' based form 'damila' was more ancient according to Krishnamurti (2003, p. 2). Thus, '*-i’ being a Proto-Dravidian feminine gender marker (Krishnamurti, 2003, p. 213), 'pide-i' (female elephant), is closely related to Tamil 'pilluvam' where the cerebral '?' is preserved, or Telugu 'piluru' where the cerebral ' '?' is replaced by ' 1 ' (as also observed by Bagchi, 1933). Pìlu is also attested as 'elephant' in Sanskrit and the middle-Indo-Aryan language Pali, whereas 'pillakā' is recorded to mean 'female elephant' in Sanskrit, whose male form, though not recorded, must have been 'pillaka' (Monier-Williams, 1872, p. 628, 630; Tin, 1920, p. 151).

The difference between ' $r$ ' in the Akkadian and Old-Persian word 'piru', and ' 1 ' in the Indic word 'pillu', is explicable by the fact that other than appearing in some rare loan-words, the phoneme ' $\mathrm{l}$ ' is often found to be absent in many ancient Iranian languages, where outlandish 'l's were often spelled and pronounced as ' $r$ 's, e.g. in Old-Persian, Babylon was called Bābiru (Klein et al., 2017; Testen, 1997, p. 582; Windfuhr, 2009). Since people of ancient Persia had functioned as intermediaries between Mesopotamian and IVC traders (Olijdam and David-Cuny, 2018; Leemans, 1960, p. 5; Oppenheim, 1954), while exporting IVC's ivory, they had arguably spread the Indic elephant-word ('pirru'<'pilu') to Mesopotamia as well. Since Akkadian is one of the earliest Semitic languages to have had contact with ancient Iranian languages, Akkadian speakers conceivably borrowed the word in its ancient Iranian form. Later and elsewhere more direct contact to non-Iranian sources possibly led to borrowing of the original 'l'-variant. Thus, certain early Seleucid cuneiform texts (ca. 300 BC) used 'pīlu', not old Akkadian 'pīru' (Stolper, 1994, pp. 20-22), whereas Middle Iranian languages such as Middle Persian and Parthian used 'pil' as their elephant-word (DurkinMeisterernst, 2004).

Exploring the etymology of this ivory/elephant word 'pilu', I find unmistakable evidence that root-words for 'tooth', used in Dravidian languages across North, Central and South Dravidian families, are 'pal', 'pella', 'pallu', 'palu' etc. (Burrow and Emeneau, 1984), whose connection with elephant/elephant-tusk words, such as 'pīlu', 'pillakā', 'palla', 'pella', (Narain, 1991; Kittel, 1894), cannot be merely coincidental. Two most unfailing taxonomical features of elephants are trunks and tusks. The most popular Sanskrit word for elephant is 'hastin'/'hastî', as the elephant-trunk seemed like a 'hasta' (hand) to Vedic people (Macdonell and Keith, 1912b, p. 172). But elephant's another moniker 'dantin' or 'tooth-haver' in Sanskrit (Bopp, 1856, p. 763), is etymologically rooted in the ancient 'danta'-based Indo-Aryan and Indo-Iranian tooth-words. 'Danta' and 'dantan' meant tooth in Rgveda (Macdonell and Keith, 1912a, p. 339) and Avesta (Reichelt, 1911, p. 234, 263), respectively, whereas words derived from 'danta' mean tooth in most of the present-day North Indian languages. Similarly, 'abu'-based Egyptian elephant-words are 
related to the Egyptian tooth-words 'abahi' and 'ảbeh' (Budge, 1920). Intriguingly, along with female elephant 'piḍ-i', whose Tamil form 'piti' is attested to in Tolkāppiyam (Murugan, 2000, p. 636), female-hog was also called 'pidi-vandi' in the tenth century Kannada classic work on Mahābhārata, called Pampa Bharatha (Burrow and Emeneau, 1984). Now, just like elephant-word 'palla', the word for hog is also 'pandri', “(literally, 'a tusker'), from the radical pal, a tusk" (Caldwell, 1875, p. 30). So, use of 'pidi-i' (phonologically and semantically related to 'pilluvam' and 'pilu') for both female hog and female elephant, the females of tuskers, cannot be coincidental. Thus, the relation between ProtoDravidian tooth-word and the Dravidian 'pal'/'pil'-based elephant-words must be deeply etymological, not accidental.

Another revealing and independent evidence of pilu's connection with the meaning of tooth comes from the widespread Indic phytonym of Salvadora persica, known in the western world as 'toothbrush tree', and in Arabic countries as 'miswak' tree; 'miswak' meaning 'tooth-cleaning-stick' (Haque and Alsareii, 2015). The obvious reason behind such tooth-related names of this tree is that its branches and roots have been used since antiquity as natural toothbrush, contain as they do several biologically active chemical constituents, considered highly beneficial for oral hygiene (Haque and Alsareii, 2015; Kumar et al., 2012). Given this, when speakers of several Indic languages call Salvadora persica as 'pilu', we need have no doubt that just like the elephant-word 'pilu', this phytonym too is related to the Proto-Dravidian tooth-word. Revealingly, Indian epic Mahābhārata (Ganguli, 1883-96) frequently associates the 'pilu' tree with regions of Indus river basin (see the section "The tooth-brush tree 'Pillu': its tooth-based etymology and ancient habitat"), proving that the 'pilu' phytonym was prevalent in Indus valley since antiquity. Moreover, Chinese travelogues of Hiuen Tsang (AD 629) tell us how an ancient toponym of Northwestern India contained the 'pīlu' word, and how certain associated legends were related with meanings of 'tooth', 'toothbrush tree', and 'elephant' (Beal, 1884, p. xcvi, 67). Phytonyms, zoonyms and toponyms being crucial cultural indicators, these evidences prove the etymological depth and spread of 'pilu' in greater Indus valley since prehistory.

My next concern is explaining how all this provides a crucial clue for exploring IVC languages. As a basic-vocabulary-item of a speech-community, which "normally does not feel any pressure to change or to resist change", 'tooth' is included in the following:

- Morris-Swadesh's 100 basic-vocabulary-items (Swadesh, 1971, pp. 282-284, Table A.1);

- Leipzig-Jakarta list of the least borrowable vocabulary, computationally created by gleaning empirical data from forty-one representative languages selected from all continents, which shares 62 items with Swadesh list (Tadmor et al., 2010);

- ASJP list of "40 most stable and effective [vocabulary] items with respect to language classification" (Holman et al., 2008 , p. 337), created by analyzing words corresponding to Swadesh's (1971) basic meaning-items collected from 245 languages (128 languages of 23 language families of the Eastern Hemisphere, 117 languages of 46 families of the Western Hemisphere); and

- Dolgopolsky's list of 23 most stable vocabulary items (Tadmor et al., 2010).

Moreover, tooth, a frequently used 'ultraconserved' vocabulary-item with cognate classes in various language families, can help us trace the deep linguistic ancestry across different Eurasian languages (Pagel et al., 2013). Now, if peoples across IVC regions had named their toothbrush-tree and tuskers with close derivatives of a Proto-Dravidian tooth-word, then they must have used that tooth-word, indicating that the basic vocabulary-items for a significant population of IVC must have been Proto-Dravidian. Thus, ancestral Dravidian languages must have been prevalent in IVC. Here, it is important to note that this study cautiously refrains from either proving or disproving the presence of any other language-group in this likely multilingual civilization.

All these points are elaborated in the sections "Results" and "Conclusion", along with a detailed discussion of how certain archaeological and linguistic evidences corroborate suggestions of certain archaeogenetic studies regarding the existence of ancestral Dravidian people in IVC.

\section{Methods}

This is an interdisciplinary research that does critical analysis of various archaeological, historical, linguistic and genetic evidence, to join many yet unconnected dots about the linguistic identities of the people of IVC. The methodology is sufficiently outlined in introductory section "How the present paper solves a part of the puzzle". Since no other experimental or statistical analysis is done, this section needs no further detail.

\section{Results}

IVC's elephant-word: archaeological and textual evidence. As Tavernier (2007, p. 35) states: "Despite the fact that Akk. [Akkadian] piru, 'elephant', is attested earlier than its OP [OldPersian] equivalents and a possible Semitic origin of pīru looks more probable at first sight, the expression's origin must be sought for in India". Deferring my linguistic arguments supporting Tavernier's insight to the section "The proto-Dravidian root of IVC's Ivory-word", I would adduce historical and archaeological evidence to prove that 'pīru'/'pīlu'-based ivory/ elephant words were at least as old as IVC, and had most likely travelled to Near East from IVC.

The age of the elephant-word pirru. The usage of 'piru' and its dialectal variations to signify 'elephant' can be traced back at least to the Old-Babylonian period (ca. 2000-1600 BC) from its use in an Akkadian wisdom tablet (Lambert, 1960, pp. 272-273). 'Pīru'based elephant-words have occurred in various Mesopotamian texts, such as: a 716 B.C. Assyrian tablet (Lambert, 1960, pp. 212-219); a Standard-Babylonian-Tablet VI of Babylonian Gilgamesh epic, and an older Middle- Babylonian version of it (George, 2003, pp. 334-335, 621); inscriptions of various Assyrian kings, including, Tiglath-Pileser I (1114-1076 BC), TiglathPileser III/IV (745-727 BC), Sennacherib (704-682 BC), and Esarhaddon (680-668 BC) (Budge and King, 1902, pp. 85-86, 139; Rogers, 1912, p. 316, 344, 354). Moreover, in an Old Persian inscription of King Darius I, the word used for ivory is 'pîruš', whereas in the Elamite version of the inscription it is written as 'pi-hi-ra-um', the '/hi/' possibly used to lengthen the pronunciation of '/i/' (Lecoq, 1997, p. 237; Vallat, 1970, p.159; Tavernier, 2007, p.35). Intriguingly, the Hurrian part of an Amarna letter of ca. 1400 BC, had used another dialectal form 'ši(in)-be-e-ru' of the Akkadian ivory-word šinni pîri (Moran, 1992, pp. 65-68; Speiser, 1940-41, p. 46). Supplementary-File-S1's Section-A contains more details about the aforementioned references.

As confirmed by the Assyrian dictionary (Roth, 2005, pp. 418-420) and the aforesaid references, 'pīru' for 'elephant' was recorded since the Old Babylonian period (ca. 2000-1600 BC) which overlaps with the latest phases of urbanized IVC (ca. 2600-1900 BC). Coinage of this word must have happened much 
earlier than its first appearance in written Mesopotamian records. Thus, despite the existence of Sumerian descriptive elephantwords such as 'til-lu-ug' (lion-killer) and 'am-si' (wild-ox with a horn) (Lewis and Llewellyn-Jones, 2018), piru-based appellatives for elephant were truly prevalent, as they were used through millennia in Akkadian, Hurrian, Old Persian (for ivory), and even Elamite languages.

The IVC origin of the elephant-word Pìru. Having established that the Akkadian elephant-word 'piru' was at least coeval with IVC, I posit that 'piru'-based elephant appellatives being first discovered from Mesopotamian records, there are two alternative possibilities of coinage to consider:

i. Elephants were indigenous to Mesopotamia, and Mesopotamians had themselves coined the 'piru'-based words;

ii. Elephants being foreign to Mesopotamia, Mesopotamians had possibly borrowed the 'piru'-based words from their ivory trading partners.

Choosing between these possibilities is complicated. For, at different periods Mesopotamians had used different sources of ivory, which included ivory imported from Tilmun/Dilmun, Meluhha, Magan, ancient Egypt, and also the ivory of the 'local' 'Syrian elephants'. Considering the Old-Persian ivory-word 'pîruš, these same questions would also be posed regarding ancient Persia's source of ivory. Following conjectures seek to answer these questions.

\section{Conjecture-1: Syrian elephants were not an indigenous species of Mesopotamia}

All elephants of our present geological era belong to two major groups: (i) African elephants (Loxodonta Africana), and (ii) Asian, also known as Indian, elephants (Elephas maximus indicus), which genetically diverged from each other since about 7.6 million years ago (Rohland et al., 2007). Regarding 'local' elephants of Mesopotamia, only 'Syrian elephants' (Elephas maximus asurus), which grazed 'between the plain of Jabbul and the Khabur basin' (Moorey, 1994, p.117), could be considered. But, though the terminology of 'Syrian elephant' makes sense in a geographical way, they were genetically not different from the Asian species, being actually "herds of an isolated sub-species of Asian elephant", who almost certainly lived in the "restricted ecological zones of northwestern Syria" from ca. 1700 to 700 BC (Frenez, 2018a, p. 18). Historical testimony of their existence comes from hunting records of various Assyrian and Egyptian kings, during 16-8th century BC, whereas physical proof of their presence comes from various nonanthropogenic natural deposits of elephant remains found from Gavur Gölü of Turkey and Habbaniyah swamp of Iraq, parts of greater Syria (Moorey, 1994, p. 117; Çakırlar and Ikram, 2016). The following longish quote of Çakırlar and Ikram (2016) clearly reveals that the Syrian elephants were most probably Indian elephants, which were imported by Mesopotamian elites with the help of IVC traders:

In Southwest Asia, the earliest representations of elephants appear in art and mythological literature, originating from eastern Lower Mesopotamia, and date to the end of the 3rd millennium BC [...] The style of depiction, though, seems to derive from that of the Indus Valley [...] This strongly suggests a second-hand knowledge of elephants, rather than first-hand, real-life experience. From Greece to Arabia, no single reference to, or depiction of, an elephant or elephant parts, ante-dates these first finds from the end of the 3rd millennium BC. This consolidates other evidence that shows that the Holocene elephants of Southwest Asia were not endemic to the region and that the Early Bronze Age peoples of the region knew about them only through their contact with India, or possibly Egypt. The latter is less likely as these animals were no longer indigenous there by that time, although remembered [...] [citations omitted].

A corroborating evidence regarding non-African origin of Syrian elephants is that not only the elephant molars of Gavur Gölü deposit, but also the preserved molars and tusks found from Izzaya, Kinet Höyük and Alalakh (located in Hatay Province on the Mediterranean coast of Turkey, i.e. part of greater Syria), like "all other elephant molars found in the region" are "easily recognizable as belonging to Asian elephants" (Çakırlar and Ikram, 2016, p. 172, 175). Now, Syrian elephants were most likely imported from IVC only since circa $1700 \mathrm{BC}$, i.e., Post-IVC period, whereas ivory was being worked on in IVC since at least 5500 BC (Moorey, 1994, p. 116) and was being imported from IVC to Mesopotamia since the middle of 3rd millennium BC (Leemans, 1960). Therefore, the possibility of coinage of the elephant-word 'piru' at Mesopotamia is very thin.

\section{Conjecture-2: IVC was the exclusive source of Mesopotamia's ivory in middle-third to early-second Millennium BC}

While Nile Delta and the southern Levant had a thriving culture of manufacturing and exchanging objects made of hippopotamus-ivory, Mesopotamia has mostly used elephant-ivory, as recorded in various Mesopotamian trade-documents (Massa and Palmisano, 2018) - "hippopotamus does not appear to be represented outside Egypt on any objects of Near Eastern origin that may be regarded as wholly independent of an Egyptian connection, nor has a term for it yet been confidently recognized in Akkadian or Hebrew or cognate languages" (Moorey, 1994, p. 115).

From mid-third up to early-second millennium BC, Sumerian and Akkadian cuneiform sources foreground three foreign lands: Makkan/Magan (Oman Peninsula), Meluhha

(Greater Indus Valley), and Dilmun (Bahrain Islands of Persian Gulf), as provenances of at least forty-two traded commodities, including elephant-ivory (Gelb, 1970; Crawford, 1998). Supplementary-File-S1's Section-B details the reasons for associating Meluhha of middle-third to early-second millennium BC with greater Indus Valley.

Among earliest cuneiform records mentioning ivory along with its geographical origin, the Third Dynasty (ca. 2112-2004 BC) Ur-texts (UET-III 761, 764, 768, 757, 777) record certain multicoloured ivory birds of Meluhha ('Gun-mušen Me-luh-ha') (Leemans, 1960, p. 33), providing a direct evidence regarding the IVC-origin of Mesopotamia's ivory. Although such figurines are not yet found in Mesopotamia, a comparable ivory bird is excavated from Tell Abraq of Magan, where source of ivory was India (Potts, 2000, p. 100, 131)

Despite Meluhha's frequent mentions as provenance of various commodities (e.g., gemstones, timbers), records of ivory-birds are the only textual evidence that directly associates Meluhha with Mesopotamia's ivory. However, Magan and Dilmun are mentioned repeatedly as sources of Mesopotamian ivory. But, as shown below, both these places had imported their ivory from IVC.

\section{Magan's source of ivory}

Magan, the crucial source of Mesopotamia's copper, was also mentioned as its ivory trading partner. "In the years 2027-2025 BC, a merchant named Lu-Enlilla, living at Ur, was charged with purchasing copper, ivory, semi-precious stones and ochre from Magan ..." (Potts, 2000, p. 54). The Ur-III tablet UET-3 751 registers 38 minas of ivory among other items imported from Magan (Laursen and Steinkeller, 2017, p. 58). But elephants were not autochthonous to Magan. In the zoo-archaeological analysis of more than 100,000 pieces of fairly well-preserved animal bones found from a long sequence of settlements (ca. late-third millennium to 300 BC) in Tell Abraq of Magan (Uerpmann, 2001), no elephant bone is mentioned. Despite this absence of local elephants, "Tell Abraq has probably yielded more ivory combs than any other site in the Near East", some of which were decorated with typical Harappan style "dotted-circles", whereas some others contained "long-stemmed tulip" designs typical of ancient Bactria (Potts, 2000, p. 100). According to Potts, the source of Tell Abraq's ivory "must have originally been the Indian elephant". Close trade ties between Magan's Tell Abraq and IVC are proven through Harappan-type cubical chert-weights found in the fortification at Tell Abraq, and Harappan-style pottery found at several of its settlements (Potts, 2000, p. 130). However, the ivory combs with distinctive tulip-designs were possibly imported from Bactria (northern Afghanistan and southern Uzbekistan) (Potts, 2000). But Frenez (2018a, p. 19) confirms that Bronze age Bactria's ivory, "might have reached the Oxus Civilization sites only from the Indus Valley, where the exploitation of Elephas maximus and its ivory dates back to the aceramic Neolithic, ca. 7000-5500 BC, and became widespread during the Bronze Age". Thus, even if some of Tell Abraq's ivory combs were imported from Bactria, their ultimate origin was IVC. Another possibility is that certain itinerant ivory carvers of IVC present in Tell Abraq crafted combs from raw IVC ivory, and decorated them with Harappan or Bactrian designs according to the local elites' taste (Frenez, 2018b, p. 393).

Many other settlements of Oman Peninsula (e.g., coastal settlements Umm an-Nār, Ra's al-Hadd, Ra's al-Jinz; interior settlements Bat, Salut, Bidbid), had pronounced presence of IVC artefacts, including Indus-style pottery (black slipped jars, fine painted wares, pedestalled dishes, perforated jars); copper axes; carnelian-beads; and ivory combs (Frenez, 2018b; Laursen and Steinkeller, 2017). Indus pottery, in particular black-slipped jars, constituted "one-third of the inventory" in Ra's al-Jinz (Laursen and Steinkeller, 2017 , p. 19), where an Indus-style ivory comb, featuring common Harappan "dotted circles", was found along with an Indus valley painted jar; a Harappan-style inscribed copper stamp seal with classic unicorn motif; and bitumen fragments from a coating of a boat, in Buildings I and II (Tosi and Cleuziou, 2007, p. 237 fig. 253; Laursen and Steinkeller, 2017, p. 19) -the archaeological context clearly relating the ivory comb with IVC.

These evidences prove that Magan's elephant-ivory was either directly or indirectly sourced from IVC. 


\section{Dilmun's source of ivory}

After Ur-III dynasty's collapse, Dilmun replaced Magan as Mesopotamia's major trading partner (Oppenheim, 1954, p. 15; Laursen and Steinkeller, 2017, pp. 50-64). Interestingly, other than dates, most of the items listed as reaching Ur from Dilmun in the latethird to early-second millennium BC, (e.g., semiprecious stones including lapis lazuli and carnelian, ivory and ivory objects, copper, silver, red gold, white corals, timbers), "came to Dilmun from elsewhere for onward shipment" (Moorey, 1994, p. xxii). Many of these items, such as lapis lazuli, carnelian, timbers (Moorey, 1994), and "fish-eye-stones" (Donkin, 1998, p. 50; Howard-Carter, 1986) were imported from IVC. Regarding ivory, various Isin-Larsa period (ca. 2000-1800 BC) cuneiform texts of Ur refer to rods, combs, inlays, boxes, spoons, and 'breastplates' made of ivory, which were donated to temples by merchants (e.g. Ea-nāsir) returning from Dilmun (Moorey, 1994; Oppenheim, 1954, pp. 6-12; Ratnagar, 1981, pp. 111-116). Now, the "prime candidate" for Dilmun's elephantivory (local dugong-ivory was also used) is Meluhha (IVC), "where a population of Indian elephants was living and [was] actively exploited" (Olijdam and David-Cuny, 2018, p. 420). The extremely close trade ties between Dilmun and IVC are manifest from: (i) prevalence of IVC's metric system in Dilmun; (ii) influence of IVC's ideological concepts on Dilmun's glyptic tradition; (iii) extensive transfer of pyrotechnical knowledge between Indus and Dilmunite craftsmen that presupposes their prolonged mixing; and (iv) existence of a steady supply chain for various IVC materials that needed "intimate personal links" between the Dilmunite and Indus traders (Olijdam and DavidCuny, 2018; Ratnagar, 1981, p. 24, 184-186). Relevantly, an important secondmillennium BC "seal-cutter's workshop" of Dilmun, which was operational for more than two centuries, contained "unfinished beads, pieces of ivory and worked shell related to production processes, a flake of obsidian, as well as small nodules of haematite, a piece of unworked carnelian, and gypsum crystals", along with five Indus-type weights in its premises (Olijdam and David-Cuny, 2018, pp. 414-415). This co-occurrence of ivory with such signature IVC products is a crucial evidence of the IVC origin of Dilmun's ivory. Moreover, after the fall of Larsa and Hammurabi dynasties, Dilmun declined into a place known mostly for its agricultural products, not for ivory, gemstones and other luxury items (Oppenheim, 1954, p. 16). This further proves Dilmun's dependence for such products on IVC, as IVC's decline happened at the same period, causing cessation of its long-distance maritime trade.

\section{Iran's source of ivory}

After elimination of Persian Gulf, Syria, and Africa as provenances of Mesopotamia's ivory in mid-third to early-second millennium BC comes Iran, where Darius's sixth century BC Susa inscriptions used a 'pirru'-based word to signify elephant-ivory. Now, as Moorey says (1994, p. 116), the "evidence for the existence of native elephants in Iran in antiquity is tendentious and unconvincing”. In the various zoo-archaeological studies conducted on pre-historic Iranian fauna, elephants are almost never mentioned (Karami et al., 2008; Young and Fazeli, 2008; Harrington, 1977; Hashemi et al., 2016). This silence on native pachyderms in Iran is explicable by the anti-elephant emotion found in ancient Zoroastrian texts, where the outlandish appearance of elephants was considered evil (Daryaee and Malekzadeh, 2017). In Bundahišn (The Book of Primal Creation), elephants are said to be a part of the demonic world, whereas in 'Pahlavi Rivāyāts' accompanying the Dädestān ì Dènīg, and another middle Persian text Dädestān ì Mènōg $\bar{\imath}$ $\mathrm{Xrad}$, the cultural hero Yima/Jam is praised for not accepting elephants from the demons, in exchange of their local cattle (Daryaee and Malekzadeh, 2017). Possibly because of this cultural resistance, even till the end of Achaemenid empire (ca. $330 \mathrm{BC}$ ) Iranians had kept themselves quite distant from elephants (Kistler, 2007, pp. 25-30) (see the section "Persian re-popularization of 'pil' and the word's Indian origin" and corresponding Supplementary section for details).

\footnotetext{
Abundance of elephant-ivory in IVC

In stark contrast to this absence of indigenous elephants in Mesopotamia, Iran, and Persian Gulf, elephants abounded in India since prehistory. Archaeologically, the earliest evidence for the working of an Asian elephant's tusks is a grooved tusk (ca. $5500 \mathrm{BC}$ ) found at Mehrgarh, a longstanding Indus settlement since the Neolithic era (Moorey, 1994, p. 116). Later, "[a] seal and a gaming piece of elephant ivory from Mundigak (III) in Afghanistan, ca. 3000 BC, are the earliest ivory artefacts so far discovered outside India" (Moorey, 1994, p. 116). Since Afghanistan "was devoid of wild elephants" (Sukumar, 2003, p. 75), and Mundigak had interactions with early phases of IVC (Cortesi et al., 2008, p. 23), these must have been IVC's ivory too. As Ratnagar (1981, pp. 111-116) says, "ivory was plentiful" in several Indus settlements (e.g., Harappa, Mohenjo-Daro, Chanhu-Daro, Lothal, Surkotda), and was "used for objects of everyday use such as containers, combs, kohl-sticks, pins, awls, hooks, toggles, gamesmen, 'batons', rods, scales, plaques, dice, inlay, furniture fittings and personal ornaments". Intriguingly, ivory was "so common at Mohenjo-daro, that bone took second place to it" (Ratnagar, 1981, p. 113). Moreover, the accurately carved elephants with manger and blankets, occurring in several Indus seals and tablets, depict a culture where elephants were not only hunted, but also tamed and trained (Ratnagar, 1981, p. 114; Frenez, 2018a, 2018b, p. 19). Additionally, India has an enormous amount of religious, economic, and historical texts-e.g., Rāmāyana, Mahābhārata, canonical Buddhist and Jain texts, several Sanskrit literary works, Arthaśāstra, ancient Tamil text Cilappatikäram/Silappathikaram)-where ivory carving, ivory artefacts, ancient ivory markets, king's control on elephant forests, and guilds of ivory-carvers and ivory-dealers are repeatedly mentioned (Dwivedi, 1976,
}

pp. 16-27). "On the contrary, there are no representations of such a majestic and aweinspiring animal in the Near East, Central Asia and the Iranian Plateau until much later periods, with the exception of a few iconographies evidently influenced by contacts with the Indus Valley" (Frenez, 2018a, p. 19).

Considering these evidences, and the fact that following "the disruption of the trade connections with the Indus valley via the Persian Gulf, in Mesopotamia archaeological evidence for ivory becomes sparse" (Massa and Palmisano, 2018, p. 73), we can confidently claim that IVC was the main source of elephant-ivory for Bronze Age Near East.

The proto-Dravidian root of IVC's ivory-word. Since archaeological evidence proves that IVC was the main source of Near East's elephant-ivory, it is logical to infer that the similar 'pirru'based ivory/elephant-words used across different Near Eastern languages (Akkadian, Hurrian, Elamite, and Old-Persian) were borrowed from languages spoken in ancient India.

This hypothesis gets direct vindication from the words phonetically related to 'pilu', which signified 'elephant' in Pali (Tin, 1920, p. 151), and in various Dravidian languages: like 'pīluru' in Telugu (Brown, 1903); 'piḷ luvam', 'pillakā' in Tamil (Madras Tamil lexicon, 1924-36); 'palla', 'pallava', 'pīlu' in Kannada (Kittel, 1894) (see the section "How the present paper solves a part of the puzzle" regarding the transformation of Indian 'pilu' to Iranian 'pīru'). Moreover, in Tamil, 'pilịu' means "to roar, as an elephant" (Madras Tamil Lexicon, 1924-36). Thus, despite the present popularity of other Dravidian elephant-words (e.g., yānai, ēnuga, āne, āna), the 'pīlu'/'pal' based elephant words too have far-reaching presence in Dravidian languages.

Now, as Kittel (1894, p. 958, 960, xxi) explained, the etymology of the Kannada elephant-word 'palla' is "one with tusks", since 'pal' means both tooth and tusk in Kannaḍa, and 'pallava', meaning 'young of an elephant', is derived from the same root. Furthermore, words for tooth in the Dravidian languages of Tamil, Malayalam, Kannaḍa, Koḍagu, Tulu, Telugu, Naikri, Naiki of Chanda, Parji, Pālu Kurumba, Gadba, Gondi, Konḍa, Manḍa, Kurux, and Malto are: 'pal', 'pallu', 'palli', 'paru', 'palu', 'pel', 'palka', etc. (Burrow and Emeneau, 1984). Considering the continued and widespread use of 'pal'-based tooth-words in both North-Dravidian and South-Dravidian, "two branches which have had no direct contact with each other in recent centuries" (Southworth, 2004, p. 236), '*pal' is reconstructed as the ProtoDravidian tooth-word (Starostin, 2006-2013; Krishnamurti, 2003, p. 47) (see Supplementary-File-S1's Section-C). So, it is no special pleading to contend that just as Sanskrit elephant-word 'dantin' is derived from Sanskrit tooth-word 'danta' (Bopp, 1856, p. 763), and Egyptian 'abu'-based elephant-words are related to Egyptian tooth-words 'abahi' and 'äbeh' (Budge, 1920), the Dravidian 'pil'/ 'pill'/'pal'-based elephant-words are also directly related to ProtoDravidian tooth-words.

Let me establish the popularity of these words in ancient Indian subcontinent with historical and linguistic evidence, before delving into the Proto-Dravidian etymology of the 'pil'based elephant/ivory words.

Hiuen Tsang's travelogue reveals that the ancient city Kapisa of Indus valley had used a toponym Pīlusāra (Pi-lo-sa-lo) for a mountain ('siang-kien' in Chinese, where 'siang' meaning 'elephant'), and that local legend relates this mountain to a "spirit that takes the form of an elephant, hence the name" (Beal, 1884, p. 67). This legend also describes the loyalty shown by this elephant-spirit to Lord Buddha, possibly signifying the mutual acceptance between Buddhism and the existing local religion. Since ancient toponyms related to religious beliefs generally use native words, 'pilu' must have prevailed as an elephant-word in the IVC regions of Afghanistan since antiquity. Interestingly, sixth century AD inscriptions found from western India's Gujarat (Sańkhēdā plate of Śāntilla) and Maharashtra (Svamīrājā's Nagardhan copper-plates) contains official designations 'mahāpilupati' and 'pilupati' which mean "great master of elephants" 
and "master of elephants" respectively, whereas as these designations were found also in Gupta dynasty's inscriptions of eastern India (Vainyagupta's 507 A.D. copper-plate from Gunaighar of Bangladesh) and have survived till twelfth century as found from various copperplate grants of Bengal's Sen dynasty (Sircar, 1965, p. 343; Dhruva, 1892, pp. 22-23; Majumdar, 1929, p. 66, 186). The Nagardhan copper-plate designates an elder member of a corporation of elephant-riders as 'pilu-pati', but calls the elephant-physician as 'hasti-baidya' (Chakraborti, 1974). This cohabitation of the Indo-Aryan elephant-word 'hastî' with the non-Indo-Aryan (Pollock, 2011, p. 43) elephant-word 'pilu' suggests that the 'pilu'-based term was too prevalent in this context to be replaced by a Sanskrit word. The prolonged usage of 'pilu' as an elephant-word is also manifest in its use in constructing other related words. For example, as attested in Sanskrit, 'pilu' also means "a group of palm trees", and "palm tree's stem" (Monier-Williams, 1872, p. 630), possibly because palm tree's stem resembles an elephant's leg (Bandyapadhyay, 1933-1946, pp. 1334-1337).

Intriguingly, as identified by Sylvain Levi et al. (1929), the ancient city 'Paloura' ('pal' + 'ura') mentioned in Ptolemy's 'Geography' (ca. 150 AD), was the same as Dantapura (Mahābhārata's Dantaküra country), the capital of ancient Kalinga (famous for elephant breeding), and the toponym's meaning was certainly "city of ivory" - 'pal' (Dravidian) and 'danta' (Indo-Aryan) meant 'ivory'; 'ura'/'kūra' (Dravidian) and 'pura' (Indo-Aryan) meant 'city' (see Supplementary-File-S1's Section-D for details). According to Levi $(1929$, p. 175), this alternation of Paloura-Dantapura "shows that in the time of Ptolemy the Dravidian language was disputing the territory of Kalinga with the Aryan dialect". In my opinion, this dispute started much earlier, since in Mahābhārata's Dantakūra, Dravidian 'pal' was replaced by Sanskrit 'danta', but the Dravidian toponymic suffix 'kūra' was yet to be substituted. This use of a Dravidian ivory-word in an eastern Indian toponym is extremely significant, since regions of eastern India were famous for elephant-breeding since antiquity, as known from various references found from Mahābhārata, Arthasasastra, and also the ancient elephant-related treatises called Gajaśästram and Hastyāyurveda written by sage Pālakāpya (Geetha, 2013; Shastri, 1919, p. 312) (see Supplementary-File-S1's Section-E for details).

Now, 'Pilu' was not a Sanskrit or Munda word. The authoritative account of the c. seventh century Mìmāmsā philosopher Kumārila Bhatța informs us that 'pīlu' meant a tree in the 'Aryan' speech, but elephant in the 'Non-Aryan' 'mleccha' languages (Bandyapadhyay, 1933-1946, p. 1336; Pollock, 2011, p. 43). Indeed, 'pal'/'pil'-based words never denoted elephants in Vedic texts (Macdonell and Keith, 1912a, 1912b). Atharvaveda merely contains a mysterious toponymic reference to a heaven called 'pilumatî' (Kuiper, 1948), along with a single phytonymic reference to some 'pilu' tree (Macdonell and Keith, 1912a, p. 535; Mayrhofer, 1996, p. 138). Thus, the entry of the elephant-word pilu in classical Sanskrit must be a late inclusion, a borrowing from non-Indo-Aryan native languages (see Supplementary-FileS1's Section-F). Similarly, the words used for elephant or tusk in the Austroasiatic Munda languages of India, display no remotest connection with the 'pal'/'pil'-based elephant words (SEAlang Munda Etymological Dictionary, 2020; Anderson, 2008). Regarding the possible Proto-Munda origin of the word 'pilu' in the toponymic word 'pilumati' of Atharvaveda, Kuiper tentatively throws in some possible semantic roots related to 'star', but hazards no Proto-Munda connection relating to the meaning of 'elephant', 'tusk', or 'ivory' (Kuiper, 1948, p. 71). In fact, these 'pal'/'pil' based elephant/ivory words are not etymologically deducible from any of the general features of elephant's anatomy or disposition (namely, 'trunk', 'tusk', 'size', 'destructivity') using the lexicon of any Indo-Aryan/Austro-Asiatic languages of India.
As mentioned above, Dravidian languages provide a direct etymological root of the '*pal'-based elephant and ivory words. Kannada elephant-words 'palla' and 'pallava' are derived from Proto-Dravidian tooth-word 'pal', using derivative suffixes 'a' and 'ava' respectively (Kittel, 1894). But, since the Proto-Dravidian tooth-word is reconstructed as '*pal', not 'pil'/'pil', Dravidian grammars cannot directly explain the Dravidian elephant-words 'pillakā', 'pilluvam' or 'piluru' as derived from the ProtoDravidian tooth-word. But Southworth (2004 p.10) helps here that reconstructed uniform invariant proto-languages are instances of "necessary idealization", where differences between regional or social dialects, and formal and informal ways of speaking are not considered. In the section "Pill'/Pil'/'Pil': alternative proto-Dravidian root-words for tooth", I argue that there is ample evidence of the existence of an alternate "*pil"based form of the Proto-Dravidian tooth-word: which was present in some ancestral Dravidian dialects, but is replaced by the 'pal'/'pel'-based tooth-words in current Dravidian languages. However, its vestiges remain in related verbs ('splitting/renting', etc.), and also in some alternate pronunciations of Dravidian phytonyms derived from the Proto-Dravidian tooth-word. Section "The morphophonemics of the elephant-word "Pilu" briefly discusses the formation of the elephant-word 'pillu'/'pilu' from this tooth-word.

\section{'Pill'/'Pill'/'Pil': alternative proto-Dravidian root-words for tooth}

\section{Evidence based on the relationship between words for 'split'/ 'bite'//'crush' and 'tooth'}

Dravidian languages often show a direct semantic and phonological relation between nouns for human limbs, and verbs associated with actions of such limbs: e.g., '*kan' 'eye' 'kāṇ’ 'to see'; '*kay' 'hand': ‘*key' 'to do' (Krishnamurti, 2003, p. 196). Now, in SouthDravidian (e.g. Tamil, Malayalam, Kannada, Telugu) and Central-Dravidian (Gadba, Parji) languages, 'pil’/'sil'-based words (e.g., 'pil', 'pila', 'pilaruka', 'piligu', 'pili', 'pīluru') mean: to tear, split, pierce, cleave asunder, divide, crush, crack, to be rent or cut, be broken to pieces, etc. (Burrow and Emeneau, 1984; Brown, 1903). Occurrence of these cognates in both South and Central Dravidian, gives this verbal root a Proto-Dravidian stature (Krishnamurti, 2003, p. 7). Now, these 'pil'-based words most likely have a semantic relationship with 'tooth', tooth being the most primitive tool, main limb, used for crushing and tearing food, or the flesh of an opponent. Note here the close relation between the Vedic Sanskrit noun 'jámbha' ('tooth', 'tusk', and 'jaw') and its related verb 'jambh' ('snap', 'shatter', 'crush', 'smash'; Indo-European root '*gemb ${ }^{\text {h') }}$, or the Vedic Sanskrit verb 'damś' ('biting'), and its related noun 'damșța' ('fang', 'large tooth', 'tusk') (Mayrhofer, 1992, p. 572-573, 688). These instances strongly make the case for an alternate 'pil'-based Dravidian tooth-word present in ancestral Dravidian languages/ dialects.

\section{Evidence based on phonological vowel variation in Dravidian cognate words}

Alternatively, 'pel'/'pil' could have been just phonological variations of the tooth-word 'pal', used in different dialects of the ancestral Dravidian languages spoken in different parts of IVC. Phonological variations in the Dravidian names of jack-fruit tree (Artocarpus integrifolia), and their tooth-related etymology, revealingly corroborate this hypothesis. Jackfruit-tree is named by 'panasa' and its cognates in many Dravidian languages: e.g. 'panas' (Kannada, Telugu), 'penac' (Parji), 'panis' (Gadba) (Burrow and Emeneau, 1984). Kittel (1894, p. xxiii) identifies 'panasa' as a Dravidian word borrowed in Sanskrit, and proposes that the Dravidian tooth-word 'pane', which means "pointed tooth, is at the root of the terms, referring to the jack fruit as covered with nail-like points". Similarly, in Sanskrit and many other Indo-Aryan languages (e.g., Bengali, Odiya, Hindi) jack-fruit is called 'kn̆ațhal', 'kaṇțakiphala', 'kaṇțaphala', 'kațhal' and 'katahal', each of which refers to its skin of pronounced 'kanțaka'/'kanța', or thorns (Turner, 1962-1966; Masica, 1979, p. 92). Since jackfruit is also called with various 'pal'based cognate words in several Dravidian languages: 'palavu', 'palā' (Tamil), 'palasu', 'halasu' (Kannada), 'palaci' (Koḍagu), I propose that these names too allude to the numerous tooth-like points on jack-fruit skin, and are etymologically rooted in the 'Proto-Dravidian' tooth-word '*pal'. The phonological transition "pal-ac- * pan-ac", and the Proto-Dravidian stature of this phytonym, is also suggested by Krishnamurti (2003, p. 12,123). Now, interestingly, jackfruit tree is also called 'pilā' (Tamil), 'pilāvu' (Malayalam), 'pila', and 'pela' (Tulu, Koḍagu) (Burrow and Emeneau, 1984; Kittel, 1894; Krishnamurti, 2003). As stressed by Subrahmanyam (1983, p. 23) the words 'pal-avu', 'pil-avu', 'pal-â', and 'pil-ā' can be segmented into root-words 'pal' and 'pil' and derivative suffixes 'avu' and 'â' respectively. Thus, paralleling 'pal-avu' \& 'pil-avu', or 'pal-ầ', 
'pil-à' \& 'pel-a', the tooth-based phytonyms of jackfruit tree clearly give us alternative root-words for tooth, i.e. 'pal', 'pil' and 'pel'. Now, since the syllable structure of ProtoDravidian is often "preserved intact in Old Tamil and Malayalam" (Krishnamurti, 2003, p. 92), the presence of the 'pil'-related root in both Tamil and Malayalam supports the conjecture that 'pil'-based tooth-words were used in some Proto-Dravidian dialects. Interestingly, in Central-Dravidian Parji, where vowels 'a' and 'à' are often pronounced and ' $e$ ' and 'e', the tooth-word is 'pel' (Burrow and Bhattacharya, 1953), whereas in North-Dravidian Malto the tooth-word is 'pāl' (Mahapatra, 1976, p. 26), demonstrating how different vowels could be used in cognate tooth-words.

In fact, such alternation between 'à', and ' $\mathrm{i}$ ' (and some other vowels) in the word-initial syllable, can be found in various other cognate words across Dravidian languages, which is arguably a common feature of Dravidian phonology. For example, as recorded by Burrow and Emeneau (1984), Krishnamurti (2003, p.123), and Subrahmanyam (1983, p. 247, 333):

i. 'Dream': 'kannavu' (Tamil, Malayalam), 'kana' (Kannaḍa, Tulu), 'kināvu' (Malayalam), konof (Toda), 'kenaci' (Koḍagu), kala' (Telugu, Kolami, Naiki of Chanda); 'kelay' (Konda, Parji), etc.

ii. Male cattle (buffalo, goat, sheep) and 'heifer': 'kațavu' (Tamil), 'kațā' (Tamil, Malayalam), 'kițā' (Tamil), 'kițāvu' (Malayalam), 'kițāy' (Tamil), 'kaḍasu' (Kannaḍa), 'kațacci' (Malayalam), etc.

Now, though the proto-forms for 'cattle' and 'dream' are reconstructed as '*kat-aca' and '*kan-ac' (Krishnamurti, 2003, p. 123), the 'i'/'e'-based alternate forms that exist in modern Dravidian languages, could have existed in ancestral Dravidian dialects too, making a strong case for the existence of the tooth-word 'pil' in certain ancestral Dravidian languages.

The morphophonemics of the elephant-word 'Pìlu'. Regarding the morphophonemics of elephant-words 'pillu'/'pillu', phonologically ' $u$ ' is the most frequent Dravidian enunciative suffix, and the last consonant of the base it gets appended to, often gets doubled (Caldwell, 1875, p. 17). Thus, along with "vil", its euphonical variants "vilu" ("vil-u"), and "villu" also mean "bow" in various Dravidian languages (Burrow and Emeneau, 1984). This explains phonologically how the enunciative 'u', added to root 'pīl'/'pil' can form 'pill-u', as well as 'pilllu' with doubled "ḷ".

Analyzing 'pìlu' morphologically, as Caldwell (1875, pp. 89-90) observes, in the ancient stage "there was no difference in any instance between the verbal and the nominal form of the root in any Dravidian dialect", and each root could be used as a verb, a noun, as an adjective without any additional formative suffixed to it (Tamil 'col'/'śol' as verb means 'to speak', as noun means 'a word'). However, gradually, when the dialects became more cultivated, certain grammatical separations started. For example, often to make a verbal noun, the root-verb's vowel gets lengthened: e.g. 'min' means 'to shine' \& 'min' means 'star' (Caldwell, 1875, p. 91). Thus, in the ancestral Dravidian languages prevalent in Northern India, the verb 'pil' ('to split, pierce, crush') might have got its vowel lengthened to form the tooth-word 'pil', which eventually formed the adjectival noun 'pillu'/'pilu', meaning 'tusker'/'elephant'. The verb 'pil' could also have formed 'pillu' (cf. Tamil 'pilluvam') by reduplicating the final consonant, to form a derivative noun of a verbal theme (Caldwell, 1875, p. 102). A similar example of such verbal nouns is the Dravidian verb 'vil' meaning 'to expand, to stretch', and its related nouns 'vil'/'vilu'/'villu' meaning 'bow' (Burrow and Emeneau, 1984). Intriguingly, a Central-Indian tribe existing since prehistoric era (mentioned in Nāradapurāṇa, Rāmāyaṇa and Mahābhārata), who are traditionally famous as archers and show significant genetic affinity (the Bhils of Gujarat) with other Dravidian and Munda tribes, allegedly derive their ethnonym 'Vil'/'Bhil'/'Bhilla', meaning 'bowmen', from this same Dravidian root 'vil' (Chaubey et al., 2017; Caldwell, 1875, p. 464). The toothword 'pill' has somehow got replaced by the 'pal'/'pel'/'pāl'-based forms in current Dravidian languages. However, 'pilu', and its cognates still mean 'arrow' in Kannada and other Dravidian languages (Kittel, 1894; Burrow and Emeneau, 1984), possibly because arrow is a weapon that pierces through its target ('pil' meaning 'to split, pierce, crush'). Since various Dravidian verbs such as 'uruvu', 'ganḍen', 'kuli', 'tai', etc., which mean 'to pierce/ to penetrate', are defined as 'to pierce through (as arrows)' (Burrow and Emeneau, 1984), the etymology of the arrow-word 'pilu' cannot possibly be anything else.

Thus, considering that the Telugu word 'piluru' means not only the verb "to tear", but also 'elephant', and "a kind of forest tree" (surely "pilu", the tooth-brush tree, see the section "Pilu': a proto-Dravidian tooth-based phytonym prevalent in IVC") (Brown, 1903), and comparing this with the Sanskrit word 'rada' that means both 'tearing/splitting/rending', and 'tooth/tusk', and the derived elephant-words 'radi' (tusked) and 'dvi-rada' (twotoothed/two-tusked) (Kittel, 1894, p. 818, 1331), I confidently claim that 'pil'/'pil'-based root-words, that meant both 'splitting/ crushing' and 'tooth/tusk', has similarly germinated the toothrelated meanings of 'elephant' and 'tooth-brush tree'. Also, as mentioned before, considering the interchangeability of cerebral ' $?$ ' and 'd' in Dravidian languages and the Proto-Dravidian feminine marker ' $i$ ', the popular Dravidian elephant-word 'pid-i' is directly related to the root-word 'pil' (Caldwell, 1875, p. 33, 59; Krishnamurti, 2003, p. 213).

Interestingly, the Indian elephant-faced-god Ganeśa is called 'Pillāri' in Telugu (Brown, 1903, p. 764); and 'Pillaiyar' in Tamil (Narain, 1991, p. 25). As suggested by Bagchi (1933) and Narain (1991), and as emphatically argued by Dhavalikar (1990), 'Pillaiyar' is derived not from the Dravidian child-word 'pilla', but from Dravidian tooth/tusk words (see Supplementary-FileS1's Section-G).

'Pilu': a proto-Dravidian tooth-based phytonym prevalent in IVC. This section analyzes the 'pilu'-based ancient phytonym of Salvadora persica, and provides another line of textual, archaeobotanical, and linguistic evidence that not only reaffirms the etymological link of 'pillu' with the meaning of 'tooth', but also links the word locationally with the regions of Indus basin and establishes the word's antiquity.

The tooth-brush tree 'pilu': its tooth-based etymology and ancient habitat. Even though 'pilu' was never used to denote elephant in Vedic literature, in Atharvaveda pilu finds mention (Macdonell and Keith, 1912a, p. 535) as a tree on whose fruits doves fed ("Tvamindra kapotayachhinnapakșāya vañcate śyāmākam pakvam pỉlu cha varasma akṛnorbahuh" Atharvaveda:20.135.12). Now, most of the phytonyms attested in Vedic texts, like 'aśvattha' and 'pippala' (Ficus religiosa), 'palāśa' (Butea frondosa), 'bilva' (Aigle marmelos), 'kharjūra' (Phoenix sylvestris), 'tila' (Sesamum), and 'śalmali' (Salmalia malabarica), have survived in India with minimal phonological changes. Likewise, Atharvaveda's 'pīlu' (phonological variations: 'pīl', 'pīlo', 'pilvu', 'piludi', 'pilun', etc.) has remained the commonest Indic name for two closely related plants of Salvadoraceae family, i.e., Salvadora Oleoides and Salvadora persica (or Salvadora indica), in various ancient and modern languages of North-India, such as Prakrit, Sanskrit, Hindi, Gujarati (Turner, 1962-1966, p. 466), Marathi, Punjabi, Bengali (Odedra, 2009, p. 315; Watt, 1893, p. 447), Odiya (Praharaj, 1931-1940, p. 4874), and Urdu (Fallon, 1879, p. 396). Among the languages of Pakistan and Afghanistan, in Balochi, Salvadora persica is called 'pīlo'/'pīlu' (Burkill, 1909, p. 47, 121), whereas in Pashto it is called 'plewan' (Watt, 1893, pp. 447-449). Moreover, both in Ayurveda, a traditional Indian medicine system (Khare, 2008, p. 574), and Tibb Yūnānī, a Perso-Arabic traditional medicine system (Ahmad et al., 2009), Salvadora persica is mostly referred to as 'pilu' and 'pilun', respectively. 
This antiquity of the phytonym 'pilu', along with its spread and preponderance over all other North Indian common names of these trees (e.g., jhak, kotungo, jhal, khabbar, kharjal), demand investigation into its etymology. Revealingly, the English common name of Salvadora persica is 'toothbrush tree'. In Middle East and the wider Islamic community, it is famous as 'miswak' (and its dialectal derivatives), which means 'toothcleaning stick' (Haque and Alsareii, 2015). These phytonyms are rooted in the use of Salvadora persica's twigs, root, and stem as toothbrush since antiquity, as they contain several bioactive components with significant antimicrobial activity against various oral and dental pathogens (Haque and Alsareii, 2015). Since Salvadora persica is a more widespread species (found in Africa, India, Iran, Israel, Jordan, Oman, Pakistan, Saudi Arabia, Sri Lanka, Syria, Yemen, etc.), compared to Salvadora oleoides (found mostly in India and Pakistan) (Orwa et al., 2009), the former tree's medicinal qualities have been more extensively investigated. However, Salvadora oleoides is also traditionally used as toothbrush in both Pakistan and India (Odedra, 2009, p. 428; Burkill, 1909, p. 47; Gratzfeld and Khan, 2015), as its root and stem possess various antimicrobial agents (Kumar, Dhankhar, et al., 2012).

Now, focusing on Salvadora persica, since both its English and Arabic names are rooted into its use as toothbrush, by corollary its ancient Indic name "pīlu", being phonologically identical to the Proto-Dravidian words used for ivory/elephant in IVC, must have shared the same tooth-based etymology. This hypothesis gets strong corroboration from the travelogue of the Chinese Buddhist pilgrim Sung-Yun (ca. 500 C.E.), which records the following old legend from Udyana, an ancient kingdom situated in Indus Valley: "Buddha once purifying (his mouth), planted a piece of his chewing stick (dantakashtha) in the ground; it immediately took root, and is at present a great tree, which the Tartars call Po-lu [...] The Pilu tree Salvadora persica" (Beal, 1884 , p. xcvi). This legend confirms that people of this Indus Valley region used a 'pīlu'-based name for Salvadora persica and associated its sticks mainly with dental care. Thus, the phytonym 'pilu' and the aforementioned toponym 'Pilusāra' establish the prevalent use of Dravidian tooth-based words to denote 'elephant', and 'toothbrush tree', in Greater Indus valley since antiquity.

In this context Mahābhärata provides an invaluable ethnohistorical testimony that a huge forest of 'Pìlu' trees existed in Indus valley since time immemorial. Here an expatriate 'Vahika' man (Mahābhārata defines 'Vahika' as people who lived near river Indus and its five tributaries), wistfully reminisced about his native land as: "Crossing the Sutlej and the delightful Iravati, and arriving at my own country [...] in the forests, having many pleasant paths of Sami and Pìlu and Karira!" (Ganguli, 1883-96, Book-8, Section-44). Additionally, Mahābhärata describes the location of a country named Aratta as a place: "where forests of Pilus stand, and those five rivers flow, viz., the Satadru, the Vipasa, the Iravati, the Candrabhaga, and the Vitasta and which have the Sindhu for their sixth" (Ganguli, 1883-96, Section-44).

Mahäbhārata's abovementioned testimony is fully supported by modern botanical and palaeobotanical Studies. Pīlu trees (Salvadora spp.), that generally flourish in arid places, saline lands and coastal regions, are one of the "key characteristic species of Pakistan's tropical dry thorn forest", which was "the prevailing woodland type in the lower hills, sandy desert areas and flood plains of most parts of the Indus basin" (Gratzfeld and Khan, 2015, p. 10). "Palaeobotanical studies carried out in Harappa [...] have revealed wood fragments of Prosopis cineraria, Acacia spp., Salvadora spp., Capparis spp., Ziziphus spp., Tamarix spp., Dalbergia sissoo and Populus euphratica", indicating that many of the floras of present-day Pakistan exists since prehistory
(Gratzfeld and Khan, 2015, p. 21). Interestingly, Salvadora spp. are among the trees that had been most regularly exploited for wood by the IVC people, as their remains "dominate charcoal assemblages thus far analysed from the Greater Indus Valley" (Fuller and Madella, 2001, p. 356; Saraswat, 1991, p. 526, 2002, p. 203). In present India, Pìlu's natural habitat comprises mostly regions of IVC (e.g., Punjab, Rajasthan, Gujarat, Haryana), and to some extent the saline soiled parts of Konkan Coast, and Andhra Pradesh (Khare, 2008, p. 574; Watt, 1893, pp. 447-449).

Analyzability of the common names of Salvadora spp. Getting sceptical regarding the etymological traceability of the Indic common names of Salvadora spp., one may question whether 'pilu' has an accidental similarity with the Dravidian tooth-word '* pal', rather than being an etymologically rooted tooth-related coinage. Now, many of the common names Salvadora spp. are evidently analyzable. For example, in Gujarat and Punjab, pilu is also called 'mithi jar' and 'khari jar' (Watt, 1893, pp. 447-449; Odedra, 2009, p. 32). While 'mītha'/'mīthum' means salt in Gujarati and Marathi, in Hindi and several other Indo-Aryan languages 'khār'/'kṣārá' signifies salt (Turner, 1962-1966). According to Odedra (2009, p. 32) these salt-based names are related to the taste of pilu sticks. However, these could also be related to the trees' natural saline-soil habitats. Similarly, pilu's Tamil name 'kalarva' most likely meant 'the tree that grows in black saline soil', as the Proto-Dravidian words such as '*kalu' and '*kalar' mean 'saline soil', and the characteristic saline soil of the Sindh region of Indus valley, a natural habitat of pilu, is called 'kalar' (Parpola, 2015). Intriguingly, these three phytonyms are semantically similar to Salvadora persica's another English name 'saltbush tree'. Thus, 'pilu', the ancient and most wide-spread Indic name of Salvadora persica, must have been a deliberate tooth-based coinage, which is semantically comparable to its most popular English and Arabic names, i.e. 'toothbrush tree' and 'miswak' ('tooth-cleaning-stick').

Tooth: a non-borrowable stable ultra-conserved vocabulary item, a credible witness for the proto-Dravidian speakers in IVC. The above sections argued that a significant segment of the IVC people must have spoken some ancestral Dravidian language (s), since they had used etymologically related Proto-Dravidian words in various meaning domains: such as body-parts (tooth), trade-commodities (ivory), fauna (elephant), and flora (toothbrush tree). But one may ask whether just one Proto-word and its associated derivative words can single-handedly determine the prehistoric linguistic affinity of a region.

Now, since a large portion of nouns of a language is often borrowed from other languages, just any noun cannot be used to identify a language's genealogy and ancestry. Here Swadesh's concept of 'basic/core vocabulary' $(1950,1971)$, typically linked to 'stability, universality, simplicity, and resistance to borrowing' (Tadmor et al., 2010), in historical and comparative linguistics, comes to our rescue. Generally, the 'cultural items' of our vocabulary (e.g. the semantic fields of religion, clothing, house, social and political relations) show high percentages of borrowing from other languages (Tadmor et al., 2010). In contrast, certain culture-free meaning domains, like the semantic fields of sense perception, spatial relations, body parts, and kinship, are quite resistant to borrowing (Tadmor et al., 2010, Table 3).

As an important and often-mentioned body-part, 'tooth' belongs to this culture-free non-borrowable basic vocabulary list. It finds mention as the 43rd item in Swadesh's list (1971, p. 283Table A.1) of 100 items, which are extensively used as a diagnostic list for glottochronological analysis across the world; gets included in the Leipzig-Jakarta list (Tadmor et al., 2010) as 
an important core-vocabulary item with a very low borrowability score and a high age score (see 'The World Loanword Database', https://wold.clld.org/meaning/4-27\#2/24.2/-4.9); secures 15th most stable position in the ASJP list (Holman et al., 2008); and 9th rank in Dolgopolsky's list (Dolgopolsky, 1986).

As explained by Holman et al. (2008, p. 334), "the words for more stable items can be identified because they have a greater tendency to yield cognates within groups of closely related languages than words for less stable items". This explains why 'pal'/'pel' based tooth-words are found to be cognates across almost all the Dravidian languages of North, Central, and South stalk (see the section "The proto-Dravidian root of IVC's ivoryword").

A recent linguistic study by Pagel et al. (2013) shows how certain frequently used words achieve a remarkable degree of replication fidelity and thus can remain 'ultraconserved' for thousands of years across genetically related languages. These scholars have computed cognate class-sizes for 188 items in Swadesh's initial 200 item vocabulary list across seven Eurasian language families. According to Pagel et al. (2013, Table S1), proto-forms of tooth-words are found to be cognates in three language families: Proto-Altaic, Proto-Dravidian, and ProtoChukchi-Kamchatkan. The underlying database used by them (https://starling.rinet.ru: Starostin, 2006-2013), documents these proto-forms as '*pala' for Proto-Altaic, '* pal' for ProtoDravidian, and '*val' Proto-Chukchi-Kamchatkan, indicating that the Proto-Dravidian tooth-word belongs to the most conserved, ancient, and stable set of words that exist in the Eurasian vocabulary, and its testimony should be sufficient to establish a speech community's linguistic identity.

\section{Conclusion}

This paper not only seeks to solve one of the most sought-after puzzles of Indology (see the section "Proto-dravidian in IVC"), but also offers certain etymologies (see the sections "Etymology of the 'pillu' phytonym was undecided till date" and "Persian repopularization of 'pil' and the word's Indian origin"), that explain some apparent inconsistencies baffling many Indian epigraphers for years. Moreover, it discusses how the linguistic and archaeological evidence presented in this paper buttresses an intriguing possibility indicated in recent genetic-anthropological studies, i.e. the North-to-South migration of Proto-Dravidian (see the section "Proto-dravidian possibly migrated from IVC to South-India: genetic evidences and linguistic missing links").

Proto-Dravidian in IVC. This paper has argued that the 'pilu'based words, which were used to convey the meanings of ivory, elephant and toothbrush tree in IVC, had originated from the Proto-Dravidian tooth-word which can be reconstructed as '*pal'/* pil'. Thus, considering that people from various parts of IVC had used a Proto-Dravidian tooth-word as a mostly nonborrowable stable part of their vocabulary, we should acknowledge that a significant portion of the IVC population spoke ancestral Dravidian language(s).

Proto-Dravidian possibly migrated from IVC to South-India: genetic evidences and linguistic missing links. In present India, there are four major language groups: Indo-Aryan, Dravidian, Austroasiatic, and Trans-Himalayan. Here, North-Indians "primarily speak Indo-European languages and have relatively high proportions of West Eurasian-related ancestry"; South-Indians "primarily speak Dravidian languages and have relatively low proportions of West Eurasian ancestry" (Reich, 2018, p. 130); Austroasiatic Munda speakers who are concentrated in the central and eastern parts show East-Asian paternal ancestry (Y haplogroup O2a) in high percentages (Tätte et al., 2019); whereas the "Tibeto-Burman in northeastern India, coincides with a high proportion of immigrant East Asian Y-chromosome O3 types" (Peter and Renfrew, 2011, p. 1390). These facts clearly show that language and genetics are strongly correlated in this subcontinent, and reaching the origin of one might reveal the origin of the other.

Now, since South-Indian Dravidian speakers are the ones who inherit the most from the ASI genetic lineage-certain Dravidian speaking tribal groups (e.g., Palliyar, Yanidi, Ulladan, Gugavellalar, Irula, Pulliyar, Adiyan, and Malayan) can be taken as nearly direct descendants of the ASI (Narasimhan et al., 2019, p. 10, Supplementary p. 290) - it is natural to infer that origins of ASI ancestry and ancestral Dravidian languages would likewise coincide. But, ASI itself was a mixed population with around $25 \%$ of Iranian-Farmer-related ancestry, and high percentages of ancestry from ancient indigenous South Asians (Reich, 2018, p.149), and was formed by the Post-IVC migration of IVC people and their mingling with the people of South and East India (Narasimhan et al., 2019). Thus, Narasimhan et al. (2019, p. 13) could not decide whether Proto-Dravidian was spread by the "peoples of the IVC along with the Indus Periphery Cline ancestry component of the ASI" or "by the half of the ASI's ancestry that was not from the Indus Periphery Cline and instead derived from the south and the east (peninsular South Asia)". An important reason behind this dilemma is that while in many cases language changes in already populated regions have strongly correlated with immigrant Y chromosomes, showing patrilingual dispersals of 'father tongues' (e.g. the Indian Austroasiatic languages, Iceland's Scandinavian languages), there are contrasting cases like Eskimo speakers in Greenland, and Tibetic language speaking Balti in Pakistan, where mother tongues have prevailed despite considerable intrusion of immigrant $\mathrm{Y}$ chromosomes (Peter and Renfrew, 2011; Driem, 2013) of other speech communities. Therefore, even if genetic data proves a North-toSouth migration of the contributors of ASI ancestry, it cannot directly establish whose language had prevailed in present South India.

Thus, if ancestral Dravidian languages had really migrated from IVC to South India, we need to prove mainly two things to establish the same:

Point-A: The ASI ancestry was formed mostly by the North-toSouth movement(s) of the IVC people, not the South-to-North movement(s) of ancient South Indians.

Point-B: Ancestral Dravidian languages were already present in IVC before the southward movement of IVC people.

Since point-A is already substantiated through various genetic studies, but is not yet widely accepted among linguists and Indologists (see opinions of different scholars in Bryant and Patton, 2005; Hock and Bashir, 2016), I have briefly re-evaluated the genetic evidence, but have kept that in Supplementary-FileS1's Section-H.

Regarding Point-B, below I shall discuss how a recent genetic study on the Dravidian speaking Brahui people supports it, and how 'pilu' adds its mite in this context. Also, in SupplementaryFile-S1's Section-I, I discuss how the computed dates of ProtoDravidian and branching of Dravidian languages (Kolipakam et al., 2018; Krishnamurti, 2003) correlate with the Post-IVC migration timings, and how certain ethnohistorical testimony of Indic religious texts support the migration theory.

Brahui and 'pilu': fillers of the linguistic missing links in Dravidian pre-history

Brahui. Brahui people, the only Dravidian-speaking population of present Pakistan, reside in Pakistan's Balochistan province, near 
Mehrgarh, one of the oldest IVC settlements (Pagani et al., 2017). Despite being separated from the Dravidian-speaking populations of southern India and Sri-Lanka, and overwhelmingly influenced by neighbouring Indo-European languages, Brahui language still carries Dravidian signature in around 300 of its lexical items, which include certain core non-cultural vocabulary items such as personal pronouns, interrogatives, a few kin terms, and verbs denoting basic concepts (Southworth, 2004, pp. 12-13). This is why some scholars argue that Brahui was one of the indigenous ancient Dravidian languages spoken in IVC (Hock and Bashir, 2016). But some other scholars, especially Elfenbein (1987), contend that Brahui language does not contain Old Iranian loans as expected of a language that stayed in the region since prehistory, but shows mostly influences from Baluchi, Pashto, and Sindhi, which according to them indicates that Brahui people had migrated to Pakistan from South only around 1000 C.E. (Hock and Bashir, 2016; Bryant and Patton, 2005). Certain linguists also debate against the Proto-Dravidian stature of Brahui (Krishnamurti, 2003). However, as explained in SupplementaryFile-S1's Section-J, rather than depending on the linguistic arguments that claim that the Brahui phenomenon is the result of a late North-ward migration of some Dravidian speaking tribe, this study gives more weightage to the empirical genetic research results discussed below that prove that the Brahui were a preexisting population of Indus valley.

Recent genetic findings show that while the Brahui people have "an ancient Dravidian genetic substrate", as "shared by all the Pakistani populations", they "do not show a higher genetic affinity with Dravidian Indians than any of their neighbouring Indo-European-speaking Pakistani populations" (Pagani et al., 2017 , pp. 270-271). Now, if the Brahui people had really migrated from South, in ca. $1000 \mathrm{CE}$, they would have shown much higher genetic affinity with the present South Indians than the other Pakistani communities, which they do not. Thus, genetic evidence conclusively affirms that "the ancestors of the Brahui people were a pre-existing Dravidian-speaking group in Pakistan", who were gradually assimilated by their Indo-European neighbours, "while their language was preserved” (Pagani et al., 2017, pp. 270-271).

Pìlu's testimony. As argued throughout this paper, three factors indubitably prove Point- $\mathrm{B}$, that Proto-Dravidian was present in IVC much before the formation of ASI: (i) the Proto-Dravidian root of 'pilu'; (ii) various archaeological, paleo-botanical, ethnohistorical and linguistic evidence that 'pilu' as a zoonym and a phytonym were coined by the ancient people of IVC; (iii) the credibility of the Proto-Dravidian tooth-word for tracing the deep linguistic ancestry of its speakers.

Another evidence of the North-to-South migration of ProtoDravidian languages possibly comes from 'kalarva', one of the most popular Tamil names of Salvadora spp. As mentioned in the section "Analyzability of the common names of Salvadora spp.", the saline 'kalar' soil of Sindh is a natural breeding ground of Salvadora spp. (Parpola, 2015). Since 'kalarva' is arguably connected to the Proto-Dravidian word 'kalar' (black soil), this Proto-Dravidian phytonym has most likely travelled from Sindh (a presently Indo-Aryan speaking IVC region in North-western India and Pakistan) to Tamil Nadu (South India).

Etymology of the 'pilu' phytonym was undecided till date. Analyzing the etymological discussion by Emeneau (1963) and probing the existing literature, I find that the present study is possibly the first study that explains the etymology of the commonest ancient Indic name of Salvadora spp., while adding another word in the list of the Dravidian loan-words present in the earliest Vedic texts. Here it is important to note that another tree Careya arborea shares the phytonym 'pilu' with Salvadora persica (Kittel, 1894). However, unlike Salvadora spp., the most common name of Careya arborea is 'kumbhi', not 'pilu' (Khare, 2008, p. 130). In my opinion, the etymology of the 'pilu' name of Careya arborea is most likely rooted in the fact that it is one of the plants that Asiatic elephants ('pilu') extensively feed on (Mohapatra et al., 2013), whereas this tree also depends significantly on elephants for effective long-distance seed dispersal (Sekar et al., 2015). The validity of this etymology is buttressed by the fact that another important plant Dillenia indica, whose fruits elephants extensively feed on too (Mohapatra et al., 2013; Sekar et al., 2015), is commonly known as 'elephant apple'. Since Careya arborea's phytonym is not directly related to tooth, it is not discussed in detail in the present study.

Persian re-popularization of 'pil' and the word's Indian origin. Despite the illuminating article by Bagchi (1933), Indian philologists have often held an opinion that the Arabic/Persian word 'fil'/ 'pil' has been borrowed as elephant-word 'pilu' in the Indian languages (e.g., Sircar, 1965, p. 326). Starting from thirteenth century, the Islamic empires of India (first Sultans then Mughals) have repopularized the Persian elephant-word 'pil' by terms like 'pilkhana', i.e. 'elephant stable' (Ray, 2019). This possibly influenced some Indian philologists to compare the Gupta period official designations 'pilupati'/'mahāpilupati' with some other known designations of Iranian influence (e.g., 'Divirapati', 'Gañjavara'), since for centuries before their time of analysis, Indo-Aryan elephant-words had mostly taken over northern Indians' active vocabulary, making 'pilu' relatable mainly to the Perso-Arabic terms 'pīl'/ffil'. In Supplementary-File-S1's Section-K, I have discussed that if one analyses the distribution of 'piru' and 'pilu' in old and new Near Eastern languages, and correlates the ca. 300 BC Seleucid administrative cuneiform texts that used the 'pilu' variant, and the Seleucid elephant army that comprised only Indian elephants received from Chandra Gupta Maurya (Stolper, 1994, pp. 20-22; Kistler, 2007, pp. 64-65), one may harbour reasonable doubt regarding the Iranian influence in the coinage of designations 'pillupati'/'mahāpīlupati', which have so successfully survived in eastern Indian Sanskrit inscriptions for at least six centuries (Gupta dynasty to Sena dynasty), without getting replaced by any other elephant-word. Supplementary-File-S1's Section-K reiterates with additional historical and linguistic evidence that irrespective of the origin of 'pilupati', the word 'pilu' had surely travelled to Persia and Iran from Indus valley, not otherwise, and its root was of purely Indian origin.

\section{Data availability}

This article has only analysed information collected from published books and articles, which are all listed in the "References" section. No other data is generated or used.

Received: 7 December 2020; Accepted: 15 July 2021;

Published online: 03 August 2021

\section{References}

Ahmad M, Zafar M, Sultana S (2009) Salvadora persica, Tamarix aphylla and Zizyphus mauritiana-Three woody plant species mentioned in Holy Quran and Ahadith and their ethnobotanical uses in north western part (DI Khan) of Pakistan. Pakistan J Nutr 8:542-547

Anderson GD (ed) (2008) The Munda languages. Routledge, New York

Bagchi PC (1933) Some linguistic notes. The Indian Historical Quarterly 9 (1):253-265

Bandyapadhyay H (1933) Bangiya sabdakosh: a bengali-bengali lexicon, vol 2 . Sahitya Akademi, Delhi, 1946/1966

Beal S (1884/2003) Si-Yu-Ki: Buddhist Records of the Western World: Translated from the Chinese of Hiuen Tsiang (AD 629), vol II. Asian Educational Services, New Delhi 
Bopp F (1856) A comparative grammar of the Sanscript, Zend, Greek, Latin, Lithuanian, Gothic, German and Sclavonic languages, vol 2 edn. 2. James Madden, London

Brown CP (1903) A Telugu-English dictionary, edn 2. Society for Promoting Christian Knowledge, Madras

Bryant EF, Patton LL (eds) (2005) The Indo-Aryan controversy: evidence and inference in Indian history. Routledge, London

Budge EAW, King LW (eds) (1902) Annals of the Kings of Assyria: the cuneiform texts with translations, tranliterations, etc., from the original documents in the British Museum. Order of the Trustees, London

Budge EW (1920) An Egyptian hieroglyphic dictionary: with an index of English words, king list, and geographical list with indexes, list of hieroglyphic characters, Coptic and Semitic alphabets, etc. John Murray, London

Burkill IH (1909) A working list of the flowering plants of Baluchistan. Superintendent Government Printing India, Calcutta

Burrow T, Bhattacharya S (1953) The Parji language: a Dravidian language of Bastar. Stephen Austin and Sons, Ltd., Hertford

Burrow T, Emeneau MB (1984) A Dravidian etymological dictionary, edn 2. Clarendon, Oxford

Çakırlar C, Ikram S (2016) When elephants battle, the grass suffers. Power, ivory and the Syrian elephant. Levant 48(2):167-183

Caldwell R (1875) A comparative grammar of the Dravidian or South-Indian family of languages. Trübner, London

Chakraborti HP (1974) Crafts and industries as reflected in the inscriptions of the Gupta Period. In: De B, Grover BR, Dua JC (eds) Proceedings of the Indian History Congress, Indian History Congress, New Delhi, 35:77-80

Chaubey G, Govindraj P, Rai N, van Driem G, Thangaraj K (2017) The genomewide analysis of the Bhils: the second largest tribal population of India. Man India 97:279-290

Cortesi E, Maurizio T, Alessandra L, Massimo V (2008) Cultural relationships beyond the Iranian Plateau: The Helmand civilization, Baluchistan and the Indus Valley in the 3rd millennium BCE, Paléorient:5-35

Crawford H (1998) Dilmun and its Gulf neighbours. Cambridge university Press, Cambridge

Daryaee T, Malekzadeh S (2017) The White Elephant: notions of Kingship and Zoroastrian Demonology. In: Patel A, Daryaee T (eds) India and Iran in the Longue Durée. UCI Jordan Center for Persian Studies, pp. 61-74

Dhavalikar MK (1990) Origin of Gaṇeśa. Ann Bhandarkar Oriental Res Inst 71 $(1-4): 1-24$

Dhruva HH (1892) Three land-grants from Sankheda. Epigraphica Indica 2:19-24

Dolgopolsky $\mathrm{AB}$ (1986) A probabilistic hypothesis concerning the oldest relationships among the language families of northern Eurasia. In: Shevoroshkin VV, Markey TL (eds) Typology, relationship and time: a collection of papers on language change and relationship by soviet linguists. pp. $27-50$

Donkin RA (1998) Beyond price: pearls and pearl-fishing: origins to the age of discoveries. American Philosophical Society, Philadelphia

Driem GV (1999) On the Austroasiatic Indus theory. Mother Tongue, Special Issue, October, pp. 75-83

Driem GV (2013) East Asian ethnolinguistic phylogeography. Bull Chin Linguist 7 (1):135-188

Durkin-Meisterernst D (2004) Dictionary of Manichaean texts, vol 3, Texts from Central Asia and China Part 1. Brepols Publishers, Turnhout

Dwivedi VP (1976) Indian Ivories: a survey of Indian ivory and bone carvings from the earliest to the modern times. Agam Prakashan, Delhi

Elfenbein J (1987) A periplus of the 'Brahui Problem'. Stud Iran 16(2):215-233.

Emeneau MB (1963) Review: Kurzgefasstes etymologisches Wörterbuch des Altindischen (A concise etymological Sanskrit Dictionary) by Manfre d Mayrhofer. Language 39:101-107

Fallon SW (1879) A new Hindustani-English dictionary, with illustrations from Hindustani literature and folk-lore. Trubner and Co, London

Frenez D (2018a) Manufacturing and trade of Asian elephant ivory in Bronze Age Middle Asia. Evidence from Gonur Depe (Margiana, Turkmenistan)Archaeol Res Asia 15:13-33

Frenez D (2018b) The Indus civilization trade with the Oman Peninsula. In: Cleuziou S, Tosi M, Frenez D, Garba R (eds) The shadow of the ancestors: the prehistoric foundations of the early Arabian Civilization in Oman, second expanded edn. Ministry of Heritage and Culture, Oman, pp. 385-396

Fuller DQ, Madella M (2001) Issues in Harappan archaeobotany: retrospect and prospect. In: Settar S, Korisettar R (eds) Indian Archaeology in Retrospect: Protohistory, archaeology of the Harrappan civilization. Manohar Publishers in association with Indian council of historical research, New Delhi, 2:317-390

Ganguli KM (trans) (1883-96) The Mahabharata of Krishna-Dwaipayana Vyasa translated into English prose, complete vols 1-18, Kindle edn. Bharata Press, Calcutta
Geetha N (2013) Elephantology and its ancient sanskrit sources. Dissertation, University of Calicut

Gelb IJ (1970) Makkan and Meluhhha in early Mesopotamian sources. Rev Assyriol Archéol Orient 64(1):1-8

George AR (2003) The Babylonian Gilgamesh epic: introduction, critical edition and cuneiform texts, vol 1. Oxford University Press, Oxford

Gratzfeld J, Khan AU (2015) Dry Woodlands in Pakistan's Punjab Provincepiloting restoration of unique yet vanishing natural assets. Botanic Gardens Conservation International, Richmond

Haque MM, Alsareii SA (2015) A review of the therapeutic effects of using miswak (Salvadora persica) on oral health. Saudi Med J 36(5):530

Harrington FA (ed) (1977) A guide to the mammals of Iran. Department of the Environment

Hashemi N, Ashouri A, Aliabadian M et al. (2016) First report of Quaternary mammals from the Qalehjough area, Lut desert, eastern Iran. Palaeontol Electron 19:1-12

Hock HH, Bashir E (eds) (2016) The languages and linguistics of South Asia: a comprehensive guide. Walter de Gruyter, Berlin/Boston

Holman EW, Wichmann S, Brown CH, Velupillai V, Müller A, Bakker D (2008) Explorations in automated language classification. Folia Linguist 42 (3-4):331-354

Howard-Carter T (1986) Eyestones and pearls. In: Al-Khalifa SHA, Rice M (eds) Bahrain through the ages. Routledge, London, pp. 305-310. 2010

Karami M, Hutterer R, Benda P, Siahsarvie R, Kryštufek B (2008) Annotated check-list of the mammals of Iran. Lynx, series nova, 39(1):63 -102

Kenoyer JM (2010) Measuring the Harappan world: insights into the Indus order and cosmology. In: Morley I, Renfrew C (eds) The archaeology of measurement: comprehending heaven, earth and time in ancient societies. Cambridge University Press, pp. 106-121

Khare CP (2008) Indian medicinal plants: an illustrated dictionary. Springer, Berlin Kistler JM (2007) War elephants. University of Nebraska Press, London

Kittel F (1894) A Kannada-English Dictionary. Basel mission book and tract depository, Mangalore

Klein JS, Joseph BD, Fritz M, Wenthe M (eds) (2017) Handbook of comparative and historical Indo-European linguistics, vol. 1. Walter de Gruyter, Boston

Kolipakam V, Jordan FM, Dunn M et al. (2018) A Bayesian phylogenetic study of the Dravidian language family. R Soc Open Sci 5(3):171504

Krishnamurti B (2003) The Dravidian languages. Cambridge University Press, Cambridge

Kuiper FBJ (1948) Proto-Munda words in Sanskrit: Verhandelingen der Koninklijke Nederlandse Akademie van Wetenschappen, afd. Nieuwe reeks, Letterkunde

Kumar S, Dhankhar S, Arya VP et al. (2012) Antimicrobial activity of Salvadora oleoides Decne. against some microorganisms. J Med Plants Res 6 (14):2754-2760

Kumar S, Rani C, Mangal M (2012) A critical review on Salvadora persica: an important medicinal plant of arid zone. Int J Phytomed 4(3):292

Lambert WG (1960) Babylonian wisdom literature. Clarendon Press, Winona Lake

Laursen S, Steinkeller P (2017) Babylonia, the Gulf Region, and the Indus: archaeological and textual evidence for contact in the third and early second millennium BC. Eisenbrauns, Winona Lake

Lecoq P (1997) Les inscriptions de la Perse achéménide. Gallimard, Paris

Leemans WF (1960) Foreign trade in the Old Babylonian Period as revealed by texts from southern Mesopotamia. Brill, Leiden

Levi S, Przyluski J, Bloch J (1929) Pre-Aryan and Pre-Dravidian in India (trans: Bagchi PC). Asian Educational Services, New Delhi

Lewis S, Llewellyn-Jones L (2018) The culture of animals in antiquity: a sourcebook with commentaries. Routledge, New York

Macdonell AA, Keith AB (1912a) Vedic index of names and subjects, vol 1. John Murray, London

Macdonell AA, Keith AB (1912b) Vedic index of names and subjects, vol 2. John Murray, London

Mahapatra BP (1976) The phonology and morphology of malto with ethnosemantic notes. Dissertation, University of Calcutta

Majumdar MG (1929) Inscriptions of Bengal, vol III. Varendra Research Society, Rajshahi

Masica CP (1979) Aryan and non-Aryan elements in North Indian agriculture. In Deshpande MM, Hook PE (eds) Aryan and non-Aryan in India. University of Michigan Press, pp. 55-151

Masica CP (1991) The Indo-Aryan languages. Cambridge University Press, Cambridge

Massa M, Palmisano A (2018) Change and continuity in the long-distance exchange networks between western/central Anatolia, northern Levan and northern Mesopotamia, c. 3200-1600 BCE. J Anthropol Archaeol 49:65-87 
Mayrhofer M (1992) Etymologisches Wörterbuch des Altindoarischen, Band I. Carl Winter, Heidelberg

Mayrhofer M (1996) Etymologisches Wörterbuch des Altindoarischen, Band II. Carl Winter, Heidelberg

Mohapatra KK, Patra AK, Paramanik DS (2013) Food and feeding behaviour of Asiatic Elephant (Elephas maximus linn.) in Kuldiha wild life sanctuary, Odisha, India. J Environ Biol 34(1):87

Monier-Williams M (1872) A Sanskrit-English dictionary etymologically and philologically arranged: with special reference to Greek, Latin, Gothic, German, Anglo-Saxon, and other Cognate Indo-European Languages. Clarendon Press

Moorey PRS (1994) Ancient Mesopotamian materials and industries: the archaeological evidence. Clarendon Press, Oxford

Moran WL (1992) The Amarna letters. Johns Hopkins University Press, London Murugan V (2000) Tolkāppiyam in English. Institute of Asian Studies, Chennai

Narain A (1991) Ganesa: a protohistory of the idea and the icon. In: Brown RL (ed) Ganesh: studies of an Asian god. SUNY Press, Albany, pp. 19-48

Narasimhan VM, Patterson N, Moorjani P et al. (2019) The formation of human populations in South and Central Asia. Science 365(6457):eaat7487

Odedra NK (2009) Ethnobotany of Maher tribe in Porbandar district, Gujarat, India. Dissertation, Saurashtra University

Olijdam E, David-Cuny H (2018) Dilmun-Meluhhan relations revisited in light of observations on early Dilmun Seal production during the City IIa-c Period (c. 2050-1800 BC). In: Frenez D, Jamison GM, Law RW, et al., (eds) Walking with the unicorn, social organization and material culture in ancient South Asia. Oxford Archaeo Press, Oxford, pp. 406-432

Oppenheim AL (1954) The seafaring merchants of Ur. JAOS 74(1):6-17

Orwa C, Mutua A, Kindt R et al. (2009) Agroforestree Database: a tree reference and selection guide version 4.0. World Agroforestry Centre, Kenya

Osada T (2006) How many proto-Munda words in Sanskrit?-with special reference to agricultural vocabulary. In: Proceedings of the pre-symposium of Rihn and 7th ESCA Harvard-Kyoto Roundtable. Research Institute for Humanity and Nature, Kyoto, pp. 151-174

Pagani L, Vincenza C, Tyler-Smith C (2017) An ethnolinguistic and genetic perspective on the origins of the Dravidian-speaking Brahui in Pakistan. Man India 97(1):267-278

Pagel M (2009) Human language as a culturally transmitted replicator. Nat Rev Genet 10(6):405-415

Pagel M, Atkinson QD, Calude AS, Meade A (2013) Ultraconserved words point to deep language ancestry across Eurasia. Proc Natl Acad Sci USA 110 (21):8471-8476

Paṇdita Sivadatta (ed.) (1894) The Hastyâyurvéda by Pâlakâpya-Muni: Ānandāśrama Sanskrit Series, No. 26. Ānandāśrama Press, Poona

Parpola A (1988) The coming of the Aryans to Iran and India and the cultural and ethnic identity of the Dāsas. Stud Orient Electron 64:195-302

Parpola A (1994) Deciphering the Indus script. Cambridge University Press, New York

Parpola A (2015) The roots of Hinduism: the early Aryans and the Indus civilization. Oxford University Press, Oxford

Peter F, Renfrew C (2011) Mother tongue and Y chromosomes. Science 333 (6048):1390-1391

Pollock S (2011) The languages of science in early modern India. In: Pollock S (ed) Forms of knowledge in early Modern Asia: explorations in the intellectual history of India and Tibet, 1500-1800. Duke University Press, Durham, pp. $19-48$

Potts DT (2000) Ancient Magan: the secrets of tell Abraq. Trident Press, UAE

Praharaj GC (1931) Purnnacandra Odia Bhashakosha. Utkal Sahitya Press, Cuttack, 1940

Ray A (2019) The Sultanate of Delhi (1206-1526): Polity, economy, society and culture. Routledge

Rao SR (1982) The decipherment of the Indus script. Asia Publishing House, Bombay

Ratnagar S (1981) Encounters, the westerly trade of the Harappa civilization. Oxford University Press, Oxford

Reich D (2018) Who we are and how we got here: ancient DNA and the new science of the human past. Oxford University Press, New Delhi

Reichelt H (1911) Avesta reader: texts, notes, glossary and index. KJ Trübner, Strassburg

Renfrew C (1987) Archaeology and language: the puzzle of Indo-European origins. Jonathan Cape, London

Rogers RW (1912) Cuneiform parallels to the Old Testament. Eaton \& Mains, New York

Rohland N, Malaspinas AS, Pollack JL et al. (2007) Proboscidean mitogenomics: chronology and mode of elephant evolution using mastodon as outgroup. PLoS Biol 5(8):e207

Roth MT (2005) The Assyrian dictionary, vol. 12. The Oriental Institute Chicago, Chicago

Saraswat KS (1991) Archaeobotanical remains in ancient cultural and socioeconomical dynamics of the Indian subcontinent. Palaeobotanist 40:514-545
Saraswat KS (2002) Paleobotanical and pollen analytical Investigations. In: Indian archaeology 1996-97-a review. Director General Archaeological Survey of India, New Delhi, pp. 198-204

SEAlang Munda Etymological Dictionary. SEALANG Munda Languages Project. http://www.sealang.net/munda/dictionary/ Accessed 9 Aug 2020

Sekar N, Lee CL, Sukumar R (2015) In the elephant's seed shadow: the prospects of domestic bovids as replacement dispersers of three tropical Asian trees. Ecology 96(8):2093-2105

Shastri H (1919) Contributions of Bengal to Hindu civilization. J Bihar Orissa Res Soc 5(3):308-324

Shinde V, Narasimhan VM, Rohland N et al. (2019) An ancient Harappan genome lacks ancestry from Steppe pastoralists or Iranian farmers. Cell 179 (3):729-735

Sircar DC (1965/1996) Indian epigraphy. Motilal Banarsidass Publishers, Delh

Southworth F (2004) Linguistic archaeology of South Asia. Routledge, London

Speiser EA (1940-41) Introduction to Hurrian. Wipf \& Stock, Oregon

Starostin G (2006-2013) Dravidian etymological database. https://starling.rinet.ru/ cgi-bin/main.cgi?flags=eygtnnl Accessed 9 Aug 2020

Stolper MW (1994). Late Achaemenid, early Macedonian, and early Seleucid records of deposit and related texts. Annali/Supplemento. 77

Subrahmanyam PS (1983) Dravidian comparative phonology. Annamalai University, Annamalai

Sukumar R (2003) The living elephants: evolutionary ecology, behaviour, and conservation. Oxford University Press, New York

Swadesh M (1950) Salish internal relationships. Int J Am Linguist 16(4):157-167

Swadesh M (1971) [2006] The origin and diversification of language. Transaction Publishers, New Jersey

Tadmor U, Haspelmath M, Taylor B (2010) Borrowability and the notion of basic vocabulary. Diachronica 27(2):226-246

Tätte K, Pagani L, Pathak AK et al. (2019) The genetic legacy of continental scale admixture in Indian Austroasiatic speakers. Sci Rep 9(1):1-9

Tavernier J (2007) Iranica in the Achaemenid period (ca. 550-330 BC): Lexicon of Old Iranian proper names and Loanwords, attested in non-Iranian texts. Peeters Publishers, Paris

Testen D (1997) Old Persian and Avestan phonology. In: Kaye AS, Peter TD (eds) Phonologies of Asia and Africa: (including the Caucasus). Eisenbrauns, pp. 569-599

Tin M (1920) Pali-English dictionary. British Burma Press, Rangoon

Tosi M, Cleuziou S (2007) In the shadow of the ancestors. The prehistoric foundations of the early Arabian civilization in Oman. Ministry of Heritage and Culture, Muscat

Turner RL (1962-1966) A comparative dictionary of Indo-Aryan languages. Oxford University Press, London

Uerpmann M (2001) Remarks on the animal economy of Tell Abraq (Emirates of Sharjah and Umm al-Qaywayn, UAE). Proceedings of the Seminar for Arabian Studies, 31:227-233

University of Madras (1924-36) Madras Tamil lexicon, 6 vols. Diocesan Press, Madras

Vallat F (1970) TABLE ÉLAMITE DE DARIUS I er. Rev Assyriol Archéol Orient 64(2):149-160

Watt G (1893) A dictionary of the economic products of India, vol 6 (part 2). W.H. Allen \& Co, London

Windfuhr G (ed.) (2009) The Iranian languages. Routledge, London

Witzel M (1999) Early sources for South Asian substrate languages. Mother Tongue, Special Issue:1-76

Witzel M (2000) The languages of Harappa: early linguistic data and the Indus civilization. http://crossasia-repository.ub.uni-heidelberg.de/120/

Witzel M (2009) The linguistic history of some Indian domestic plants. J Biosci 34 (6):829-833

Witzel M (2019) Early "Aryans" and their neighbours outside and inside India. J Biosci 44:58

Young R, Fazeli H (2008) Interpreting animal bones in Iran: considering new animal bone assemblages from three sites in the Qazvin Plain within a broader geographical and chronological perspective. Paléorient 153-172

\section{Acknowledgements}

I am grateful to Professor Steffen Terp Laursen for kindly sharing his book with me. I cordially thank Professor Michael Witzel for sharing his paper, and for making important comments on a pre-print version of the article. I also thank Sanskrit scholar Nrisingha Prasad Bhaduri for confirming an important reference. I thank technologist and entrepreneur Dr. Gopichand Katragadda, and Dravidianist Indologist R. Balakrishnan for commenting on some of the Dravidian etymologies I have proposed. I am grateful to Bhaskar M. Venkatraman, an Indus Valley civilization scholar, for reading my manuscript several times and making important comments on my arguments. Finally, I am deeply indebted to Amartya Mukhopadhyay, Professor (Retd.), Political Science, University of Calcutta, for repeatedly going through my manuscript to ensure that the English is lucid. 


\section{Competing interests}

The author declares no competing interests.

\section{Additional information}

Supplementary information The online version contains supplementary material available at https://doi.org/10.1057/s41599-021-00868-w.

Correspondence and requests for materials should be addressed to B.A.M.

Reprints and permission information is available at http://www.nature.com/reprints

Publisher's note Springer Nature remains neutral with regard to jurisdictional claims in published maps and institutional affiliations. (c) (i) Open Access This article is licensed under a Creative Commons Attribution 4.0 International License, which permits use, sharing, adaptation, distribution and reproduction in any medium or format, as long as you give appropriate credit to the original author(s) and the source, provide a link to the Creative Commons license, and indicate if changes were made. The images or other third party material in this article are included in the article's Creative Commons license, unless indicated otherwise in a credit line to the material. If material is not included in the article's Creative Commons license and your intended use is not permitted by statutory regulation or exceeds the permitted use, you will need to obtain permission directly from the copyright holder. To view a copy of this license, visit http://creativecommons.org/ licenses/by/4.0/.

(C) The Author(s) 2021 